San Jose State University

SJSU ScholarWorks

Master's Theses

Master's Theses and Graduate Research

1994

\title{
Oral histories of black gay men and a black transgender person in the San Francisco Bay Area
}

Nina Schjelderup

San Jose State University

Follow this and additional works at: https://scholarworks.sjsu.edu/etd_theses

\section{Recommended Citation}

Schjelderup, Nina, "Oral histories of black gay men and a black transgender person in the San Francisco Bay Area" (1994). Master's Theses. 802.

DOI: https://doi.org/10.31979/etd.3427-p69v

https://scholarworks.sjsu.edu/etd_theses/802

This Thesis is brought to you for free and open access by the Master's Theses and Graduate Research at SJSU ScholarWorks. It has been accepted for inclusion in Master's Theses by an authorized administrator of SJSU ScholarWorks. For more information, please contact scholarworks@sjsu.edu. 


\section{INFORMATION TO USERS}

This manuscript has been reproduced from the microfilm master. UMI films the text directly from the original or copy submitted. Thus, some thesis and dissertation copies are in typewriter face, while others may be from any type of computer printer.

The quality of this reproduction is dependent upon the quality of the copy submitted. Broken or indistinct print, colored or poor quality illustrations and photographs, print bleedthrough, substandard margins, and improper alignment can adversely affect reproduction.

In the unlikely event that the author did not send UMI a complete manuscript and there are missing pages, these will be noted. Also, if unauthorized copyright material had to be removed, a note will indicate the deletion.

Oversize materials (e.g., maps, drawings, charts) are reproduced by sectioning the original, beginning at the upper left-hand corner and continuing from left to right in equal sections with small overlaps. Each original is also photographed in one exposure and is included in reduced form at the back of the book.

Photographs included in the original manuscript have been reproduced xerographically in this copy. Higher quality $6^{n} \times 9^{n}$ black and white photographic prints are available for any photographs or illustrations appearing in this copy for an additional charge. Contact UMI directly to order.

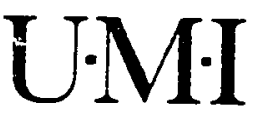

University Microfilms International

A Bell \& Howell information Company

300 North Zeeb Road. Ann Arbor. MI 48106-1346 USA

313:761-4700 800:521-0600 

Order Number 1358226

Oral histories of black gay men and a black transgender person in the San Francisco Bay area

\author{
Schjelderup, Nina, M.A. \\ San Jose State University, 1994
}

$\mathrm{U} \cdot \mathrm{M} \cdot \mathrm{I}$

300 N. Zeeb Rd.

Ann Arbor, MI 48106 

ORAL HISTORIES OF BLACK GAY MEN AND A BLACK TRANSGENDER PERSON IN THE SAN FRANCISCO BAY AREA

\author{
A Thesis \\ Presented to \\ The Faculty of the Department of Social Science \\ San Jose State University \\ In Partial Fulfillment \\ of the Requirements for the Degree \\ Master of Arts
}

by

Nina Schjelderup

May 1994 
(C) 1994

Nina Schjelderup

Ail Rights Reserved 
APPROVED FOR THE DEPARTMENT OF SOCIAL SCIENCE
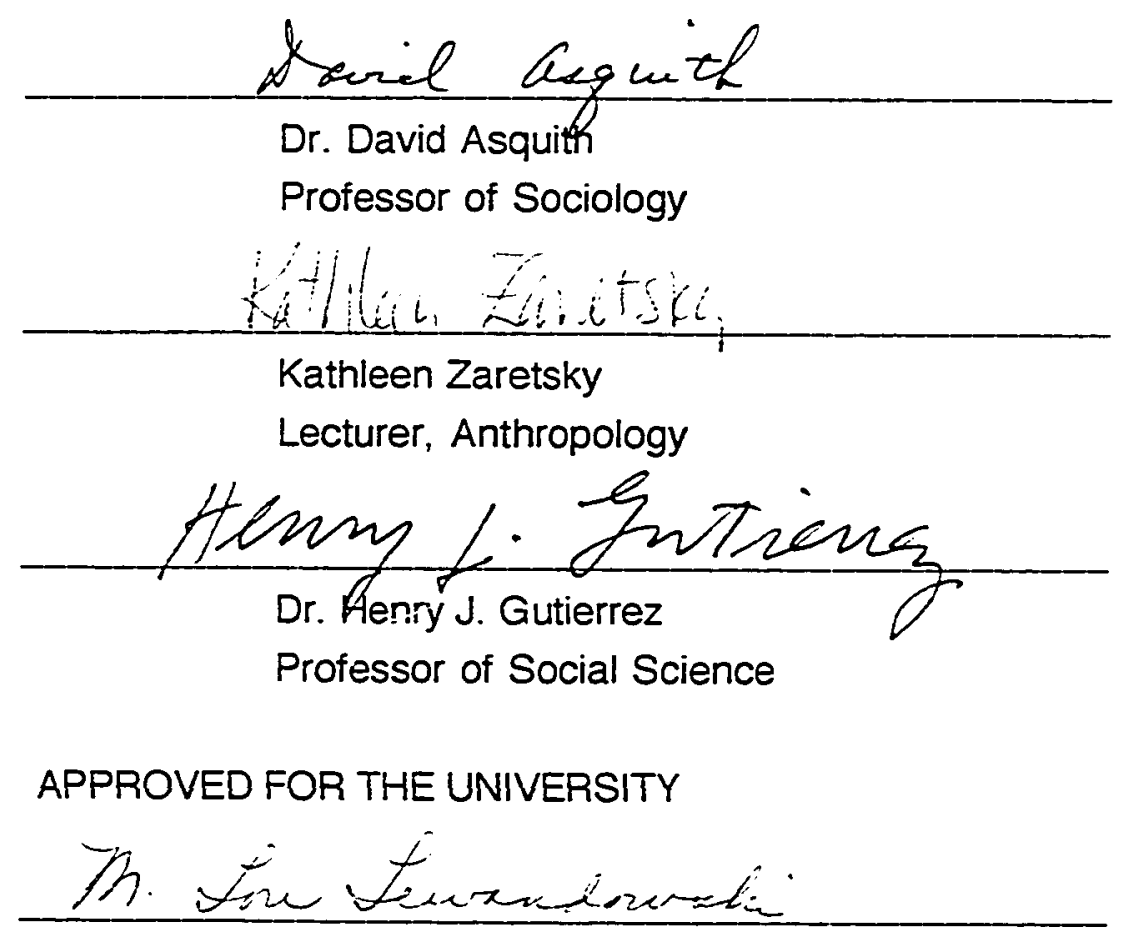


\section{ABSTRACT \\ ORAL HISTORIES OF BLACK GAY MEN AND A BLACK \\ TRANSGENDER PERSON IN THE \\ SAN FRANCISCO BAY AREA}

by Nina Schjelderup

This thesis addresses the topic of the lives of black gay men and transgender people, using the disciplines of anthropology and sociology. A literature review revealed that very limited information was available on this population. Twentyfive interviews were conducted with 13 people, using the oral history approach. The goal for this study has been to collect information about what the thirteen people interviewed see as important in their lives, and to contribute to a better understanding of a group of people little research has been devoted to in the past.

Some of the topics addressed are: family relations, racism in the gay community, homophobia in the black community, choice of partners, relationships with women, and the process of defining a gay or transgender identity. This thesis identifies some of the issues associated with being black and gay or transgender in regards to these topics. 


\section{DEDICATION}

to my friend hamilton

i love you

to marlon t. riggs

your work will live on 


\section{ACKNOWLEDGEMENTS}

To the thirteen people who shared with me a part of their lives.

To Dr. David Asquith for being the chair of my thesis committee and giving me support.

To Kathleen Zaretsky for showing an interest in this project and for sharing the true spirit of anthropology with me.

To Dr. Henry J. Gutierrez for being part of the thesis committee and making this happen.

To my dear proof readers Christy, Joanie, Betsy, and Leann for making this thesis, and my data, readable.

To friends and family who supported me along the way.

To Michael Sullivan for showing an interest in this project and giving me the opportunity to speak with some great people. 


\section{TABLE OF CONTENTS}

Chapter

Page

I. INTRODUCTION

A. Background and Topic Selection ..................................... 1

B. Research Circumstances and Biases .............................. 2

C. Terminology ....................................................................

D. Literature Review ............................................................. 4

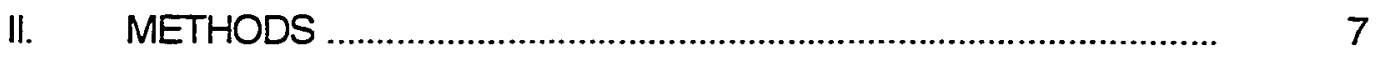

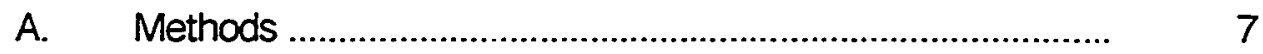

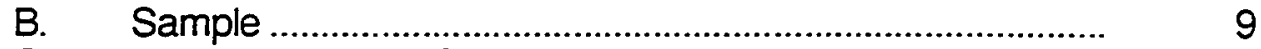

C. Limitations of this Study _................................................ 13

III. CULTURAL IDENTITY _................................................................ 15

A. Partners and Racism .......................................................... 16

B. Homophobia ................................................................ 23

C. Role of Women ................................................................ 27

D. Summary of Findings ....................................................... 28

E. Analysis ......................................................................... 29

1. Partners and Racism ................................... 30

2. Homophobia ............................................. 34

3. Role of Women .............................................. 38

IV. DEFINING GAY IDENTITY ......................................................

A. Childhood and Adulthood ................................................... 41

B. Coming Out ..................................................................... 44

C. Summary of Findings ........................................................... 46

D. Analysis ......................................................................... 47

1. Childhood and Adulthood ........................... 47

2. Coming Out .................................................... 53 
V. RELATIONSHIP TOFAMILY .................................................. 56

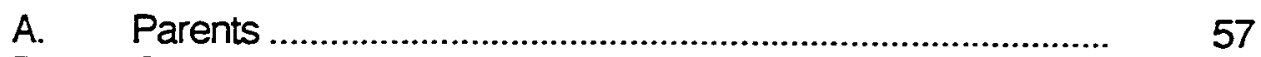

B. Other Family Members ....................................................... 60

C. Summary of Findings ........................................................... 64

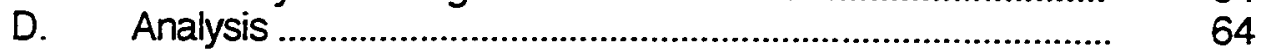

1. Parents ................................................................. 65

2. Other Family Members ............................................ 67

3. The Concept of Family ........................................... 68

VI. TRANSGENDER ISSUES ........................................................ 71

A. Prejudice ........................................................................

B. Partners .......................................................................

C. Transgender Identity ....................................................... $\quad 75$

D. Family ......................................................................... 77

E. Summary of Findings ...................................................... 80

F. Analysis ........................................................................ 80

1. Prejudice .................................................................. 81

2. Partners ........................................................... 83

3. Transgender Identity ........................................... 84

4. Family .................................................................. 85

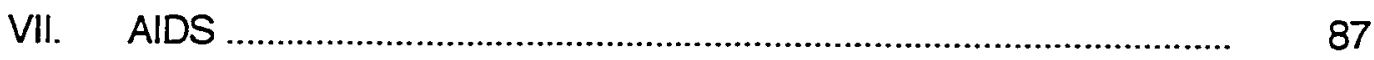

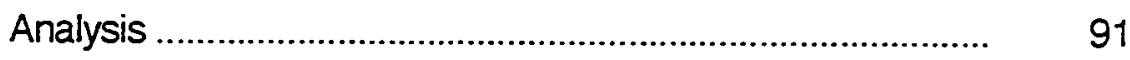

VIII. RELIGION AND SPIRITUALITY .............................................. 95

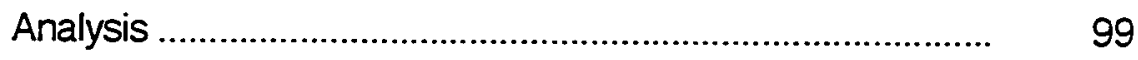

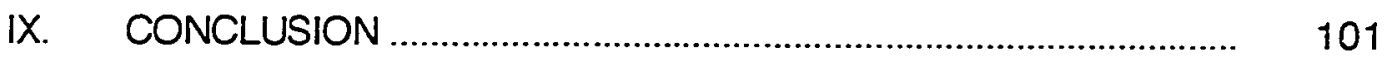

REFERENCES 


\section{INTRODUCTION}

This study evolved from my interest in gender-roles in anthropology. Personal experiences with gay friends and people of color, both in America and in my native country of Norway, have resulted in my concern with the lack of knowledge and understanding of gays and people of color. I have done a research project based on oral histories of twelve black gay men and one transgender person. My background in the social sciences has led me to believe that knowledge and understanding of some of the issues concerning black gay men can be understood more clearly through the eyes of black gay men themselves. Consequently, the goal of this study has been to collect information about what the thirteen people interviewed see as important in their lives, to contribute to a better understanding of a group of people to whom little research has been devoted in the past.

\section{A. BACKGROUND AND TOPIC SELECTION}

My awareness of homosexuality and homophobia intensified when I realized that one of my friends was gay and saw how much he suffered as a result of it. I became aware of and interested in the social taboos concerning sexuality in the United States.

When I first came to California as an exchange student from Norway in 1981, I was surprised to see that many black people were treated as second class citizens. The few black Americans that I had encountered in Norway had a rather high status there. I was young and puzzled by this contradiction, and I started wondering why it was "cool" to be a black American in Norway, but bad to be a black American in America. This triggered for me an interest in the black movement in the United States.

These experiences later led to an academic interest in gender roles, in general, and homosexuality, in particular. When I started talking with more and more people in the gay community in San Francisco, and reading some of the gay 
literature, I realized that, contrary to what people on the outside might think, racism is alive and well within the gay community. After looking into different groups of gay people of color, I decided to base this study on black gay men. This decision was based on my personal interest in the history of AfricanAmerican people in the United States, as well as on the fact that somewhat more information is available on this gay group of people of color than on any other one group. From the information I had available, it also became clear that more groups and organizations had been formed for and by black gay men. As a result, I concluded that it would be easier to find black gay men to interview than other gay men of color.

\section{B. RESEARCH CIRCUMSTANCES AND BIASES}

Since this is an ethnographic study, it is important to establish some of the subjective circumstances that the researcher brings into the study, as well as to address some potential biases. For the sake of defining my approach in terms of my background, it is important to keep in mind that 1 am not gay or transgender. I am not male, and I am not a person of color. I am not even an American, although most of my cultural framework is drawn from the United States. I believe these facts can be both to my advantage and disadvantage. On one hand, I cannot relate the experiences of black gay men in America to my own reality as a white heterosexual female from Norway to the same extent that a person with a more similar background can. On the other hand, I can approach the interviews with fewer assumptions, and my data with more objectivity than someone sharing more similar characteristics with the people interviewed. As Karl, age 31, said during our interview: "I think that you, as an anthropological person, have the opportunity, if you are open to it, to really take a good look. Some of us are too caught up. We are too busy performing and reacting, and too busy trying to get the approval, instead of taking a look. A lot of us don't see what we're doing." 


\section{TERMINOLOGY}

I will use the terms black and African-American interchangeably. The people I spoke with used one term or the other, some opposing the other, as Lang, age 52, said during the interview:

I rarely use the term African-American. I don't feel that African-American is universal. I feel that the race I belong to is universal and that's the black race. It's all over the continent. Jesse Jackson came up with that hyphen, which I'm sorry he ever did. It's just not powerful enough. I know you have terms like Chinese-American too, but Chinese should be enough. This planet belongs to everybody.

None of the people I spoke with used the term bisexual to define themselves, despite the fact that a number of them had had relationships with women previously. One person had been married, but was divorced, and one was still married. These two people had three children each.

The question "what comes first, being black or gay," is a question many black gay men are being asked. Some use the term gay black, indicating that being gay comes first. Most of the people I spoke with, however, used the term black gay, claiming that being black was most important since they could choose to hide their sexuality, but not the color of their skin. I will therefore use the term black gay. One person used the term "men who love men" rather than gay.

The exact definition of different gender roles varied in the limited literature I have been able to find. I will use the definitions given to me by Mira, the transgender person I interviewed, and compliment them with some of the literature. Also, some of the literature indicated that there are more than two genders. Mira said that she considers transgender people as a third gender. Still, I have chosen to define gender as either male or female for the purpose of this study. 
Transgender. I will use Mira's definition: "Transgender is kind of like the whole spectrum, all the way from the cross dressers, to the people who occasionally dress, to the people like me who have had complete surgery, and everything in between." Cross-dressers dress up as a fetish. The term transsexual describes a person "who has presented a lifelong history of gender dysphoria, a history of cross-gender identity, and an absence of fetishism associated with cross dressing. Sexual preference is usually homosexual from an early age" (Docter, 24). A transvestite is a heterosexual male who cross-dresses. A drag queen usually dresses for money or for entertainment--a female impersonator. I will mostly use the term transgender in this study, since that is the term Mira uses to define herself.

\section{LITERATURE REVIEW}

The book Black Masculinity was written by Staples and published in 1982. In the chapter "Homosexuality and the Black Male," he drew his information from a study of 500 black, college educated singles, of whom approximately 110 were male and 20 identified as being homosexual or bisexual. Over two thirds of the black gay sample said that half of their sexual partners had been white. The study also indicated that black gays did not find a high degree of acceptance in the black community. However, they were less likely to hide their homosexuality from their family and friends than their white counterparts.

In her 1983 article, "The Failure to Transform: Homophobia in the Black Community," Clarke attacked the sexual politics of the black liberation movement. She concluded by claiming that the only way for the black liberation movement to be liberated from the white power system was to break down the homophobic power structure within the black community.

In the article, "Black Gay Men and Conflicting Social Identities: Sexual Orientation Versus Racial Identity," published in 1986, Icard discussed the identity problems of black gay men and gave some implications for social work. He claimed that the black community was homophobic, to a large extent, 
because the black church preached that homosexuality was a sin. Further, black gay men were not received well in the gay community because of attitudes often based on sexual racism. Sex role stereotypes became linked to racial stereotypes and most black gay men were looked upon as feminine. He concluded by emphasizing that, in order for social workers to serve this population well, they needed to understand these and other cultural dynamics of black gay men.

In the paper, "Growing Up Gay or Lesbian in a Multicultural Context," published in 1989, Tremble, et al., interviewed ten young ethnic gays between the ages of 16 and 21 regarding family relations. Their findings indicated that although ethnic gays and lesbians experience greater stress than their white counterparts--due to cultural differences-family relations depended more upon the qualities of the family and the gay child, rather than their ethnic background.

In the book, Brother to Brother, edited by Essex Hemphill, conceived by Joseph Beam, and published in 1991, Hemphill and Beam collected writings by and about black gay men. This probably represent the largest collection of published materials by and about black gay men, and functioned, therefore, as an important foundation for this thesis. In this book's introduction, $(x x x)$, Hemphill wrote:

There are areas that this anthology, in a formal fashion, does not speak to, such as narratives from older black gay men and black gay couples; spiritual concepts and beliefs; career experiences; community and political activism; historical and biographical reconstructions; health care issues beyond AIDS; interracial relationships; our relationships with women; and numerous other subjects. The density of the silence surrounding our lives does not make it easy to gain this information.

This was kept in mind during the formation of the questions used for this thesis. Most of these topics are addressed by people interviewed. 
In the paper, "Atitudes Toward Minorities: A Comparison of Homosexuals and the General Population," published in 1992, Beran, et al. presented a study based on questionnaires regarding attitudes towards gays and other minorities. The study had two samples: one from the population at large and one sample of gays and lesbians. The study found that the gay sample expressed more liberal attitudes toward other minorities, than did the population at large.

In the article, "Bias From Within Against Black Gays," published in 1993, White pointed to a study by the Center for Disease Control, indicating that blacks were nearly three times more likely than whites to contract AIDS. In addition, a report by the San Francisco Health Department stated that young gay blacks had the highest HIV infected rate--21 percent--in the city, while the rate among Latinos was nine percent and eight percent among whites.

Bullough and Bullough, in their 1993 book, Cross Dressing, Sex, and Gender, discussed gender roles from an intercultural perspective. Their conclusion was that research had not yet given definite answers about the source of gender identity or sexual orientation. Rather, the understanding was increasing and it can be said that both gender identity and sexual orientation are the result of a combination of nature and nurture. 


\section{I! METHODS}

\section{A. METHODS}

This research is based on letting people talk about their own lives and the issues important to them, so it lends itself to a qualitative study and, consequently, to the oral history approach. Another reason for using oral history was that, after researching the literature by and about black gay, the existing literature showed only fractions of people's realities presented, usually with a strong emphases on only one issue in their lives. This research is based on questions concerned with various aspects of people's lives. This has been done in an attempt to present the issues with more of a whole-person approach.

Twenty-five interviews were conducted over a two month period of time, tape recording all of them. Three people were interviewed three times, six people were interviewed two times each, and four people were interviewed one time each. The interviews were time-consuming since most of them were conducted in San Francisco and Oakland. The tapes were transcribed as soon as possible after the interviews were completed. All identifying information was removed in the process of transcribing the tapes. Names are used when quoting from the data so that the ideas of one person can be followed. However, real names are not used.

Each interview lasted from one to four hours, with most of them lasting two hours. Most of them took place in the homes of the people interviewed. However, three people were interviewed in their offices, and one subject was interviewed three times in a friend's apartment. Most of the people interviewed were very open and not hesitant to disclose personal information. Most people expressed themselves in a very colorful and refreshing way, with frequent use of humor. This particular form of expression is valuable as part of the findings, so extensive quotes will be used from the interviews in order to reflect this. The 
format of the interviews was open-ended, so people freely associated from one subject to another.

Some of the issues addressed in the interviews were: the type of family and community support the person had; relationships; personal identity with black versus gay communities; racism and homophobia; and the process of defining gay or transgender identity. The theoretical and conceptual framework used included cross-gender behavior in different societies and the history of the black and gay movements.

In looking at homosexuality and cross dressing in a global perspective, one will find the existence of gender variations in nearly all societies. The social reaction to it varies. In India, for example, the hijra serve an institutionalized third-gender role. Hijras dress as women, wear their hair long, take women's names, and use a feminized vocabulary (Bullough, 8). Performing a function similar to the hijras in India are the xaniths in Islamic Oman. Xanith in Arabic means "impotent," "effeminate," or "soft." They are biological males, but are not, unlike the hijras, castrated. They have masculine names, and under Islamic law have all the rights of a man. They are like women in that they perform household work, but are recognized as homosexuals (Bullough, 11). These and other examples of cross dressing and gender roles in different societies were part of the conceptual framework.

Part of the historical framework is used because a number of the people in the sample were old enough to have lived through years of segregation before the civil-rights movement started. These experiences frequently surfaced as historical reference points for a number of the people during the interviews. Also, some people in the sample had been part of the gay movement, often in terms of fighting racism within the gay community.

Oral history as a research method is used in most social sciences. Oral history, when used as the history of the life of an individual person, is used in the humanities, psychology, and in the social and medical sciences for a wide array of purposes and with varying degrees of success. In this age of interdisciplinary 
and behavioral science research, there is reason to believe that the oral history approach to human behavior offers a valuable common denominator for scholars in many disciplines.

Oral history has been used extensively in anthropology. In the pre-1925 era, this took the form of nonprofessional biographical and autobiographical studies of a sentimental, romantic kind, the purpose of which was to show the "noble savage" at his best, and with wide, popular appeal. Largely due to the influence of Paul Radin and Edward Sapir, the first professional interest within the field of anthropology was shown in personal documents around 1925. Between 1925 and 1944 there was a growing interest in the use of oral history material and in methodology and the problems of methodology in general (Langness, 19).

During this same period of time, the interest in culture-and-personality stimulated by Sapir, Ruth Benedict, Margaret Mead, and others was creating still further interest in the individual and in psychology. These two trends met in 1944-45 and, with the publication of Kardiner's The Psychological Frontiers of Society, new importance was attached to oral histories. The anthropological interest was formally expanded to include personality as a significant unit for analysis. Neither Kardiner's use of orai histories nor Kluchon's arguments for their use resulted in an extensive development of the oral history, although some good studies were stimulated. The interest, which peaked between 1925 and 1945, appears to have diminished somewhat and there has been an emphasis on less time-consuming and less difficult methods of gathering data (Langness, 19).

\section{B. SAMPLE}

In finding subjects to interview, a letter was written to introduce the research, and sent to a number of gay organizations in the Bay Area. This resulted in a few phone calls. Then four black gay activists were contacted, and they all agreed to participate. Also, potential subjects called after the interviewing had started, following word of mouth from other people interviewed. 
An effort was made to find people with different backgrounds, but the sample is not a representative one. For legal purposes, minors were not interviewed. The people interviewed were between 23 and 60 years of age. The majority were between 30 and 42 years. About half the people had completed a Masters degree or equivalent, with one year of Junior College being the lowest educational level of any of the people. Almost all were professionals, and most considered themselves social and political activists, fighting for both black and gay rights. They were resourceful people, and they brought to the research a very different perspective than a younger, less educated sample would. According to a study by Bell and Weinberg entitled, "Homosexualities," "Black male homosexuals tend to be younger than their white counterparts, an average age of 27 in contrast to 37 for white males. They had less education and were employed at a lower occupational level than white gays." (Staples, Singles, 201). The average age for this sample was 41.

Even though the sample was not representative in age, many of the people interviewed worked for and with younger and less educated black gay men. However, the patterns found in many of the stories of the people interviewed are valuable as they stand.

Four of the 13 people interviewed were part of the "non-written sample." This means that the interviews conducted were not transcribed, so they are not qucted. When realizing the amount of data collected, more than 300 pages of written material. a decision was made not to transcribe the interviews of the four people interviewed only one time. Two of these four people had very busy schedules and it was difficult to set up another interview time with them. Since the data was incomplete at that time, they were not included in the written sample. The third person interviewed only one time talked about issues very similar to those of the rest of the sample, so the same information could be used from the existing material. The fourth person in the non-written sample was very different from the other people, without much connection to any gay or black community. Since the interview questions, to a large extent, were based on this connection, it was sufficient to use the notes taken during the interview. 
These are some personal data of each person in the sample, using the names they have been given for the purpose of keeping them anonymous in this study:

(Andy - not part of the written sampie): 36 years of age. Artist. One year of Junior College. Parents divorced when he was in fifth grade. Not religious. Lived by himself. Grew up in a white middle-class neighborhood. One interview conducted.

Bern: 30 years of age. AIDS educator. Grew up in Southern California. Was close to mother and grandparents. No contact with real father. Three years of college. Lived by himself. Two interviews conducted.

Conrad: 51 years of age. Teacher. Grew up in the South. Had AIDS. Parents divorced at age 9. Was close to mother who remarried twice. Was not close to father while growing up, but got closer later on. Lived with partner. Raised by mother and grandparents. Master's degree. Three interviews conducted.

Dave: 41 years of age. Writer and video producer. Grew up in the Mid-West. Parents divorced at age 13. Very close to grandparents. Father had passed away three years ago. Was close to aunt. Close to mother. Lived with white partner. Master's degree. Three interviews conducted.

Eric: 36 years of age. Business executive. Married with three children. Grew up in the Mid-West with thirteen sisters and brothers. Religious. Had just come out and had, at the time of the interviews, not had any homosexual experiences. Master's degree. Three interviews conducted.

Frederic: 60 years of age. Physician. Grew up on the East Coast. Both parents passed away. Originally from the West Indies. Started living a homosexual lifestyle after his divorce when he was in his 50s. Had three children. Medical school. Lived by himself. White partner. Two interviews conducted. 
(Garry - not part of the written sample): 42 years of age. Grew up in a housing project in a black neighborhood in the Mid-West with eight brothers and sisters. Mother raised the children by herself. Had gone through a wedding ceremony with his white partner. Worked for an organization doing AIDS-related work. Had tested HIV positive. Three years of college. One interview conducted.

(James - not part of the written sample): 57 years of age. Grew up on the East Coast in a predominantly white neighborhood. Worked for an organization doing AIDS related work. Lived by himself. Has a Master's degree. One interview conducted.

Karl: 31 years of age. Runs a human service organization. Grew up in Southern California. Grew up with mother and father-figure, who divorced when he was 15. Abusive father-figure. Very close to mother. Bachelor's degree. Lived by himself. Two interviews conducted.

Lang: 52 years of age. Nurse and health educator. Master's degree. Grew up in the South. Mother left when he was 9. Grew up with father and grandparents. Close to mother today, not while growing up. Father alcoholic, passed away when Lang was 15. Had tested HIV positive. Two interviews conducted.

Mira: 34 years of age. Counselor. Transgender - identified as a woman. Was very close to parents who passed away shortly before the interviews took place. Grew up in the Bay Area. Three semesters of college. Lived by herself. Two interviews conducted.

Ned: 37 years of age. Master's degree. Restaurant owner. Grew up in the Bay Area. Parents divorced. Mother passed away. Mother was white, father was black. Was never close to abusive mother. Was close to father. Had AIDS. Lived by himself. Two interviews conducted.

(Oscar - not part of written sample): 23 years of age. Was a student and worked as a research associate. Four sisters and brothers. Parents separated. Not 
close to father, but somewhat close to mother. Lived with a roommate. His partner for the past two years had been a white male, 34 years of age. One interview conducted.

Mira's issues will be discussed in a separate chapter from the others because her issues as a transgender person were different than those of the gay sample.

A number of the people interviewed expressed the view that the interviews had been good therapy for them. Eric, age 36, was just coming out at the time of the interviews:

Part of the reason why I agreed to do this, is because it gives me an opportunity to say some of the things that I'm thinking out loud to a disinterested party. Not disinterested to the point where they don't have any degree of sensitivity to my plight, but disinterested to the point where there is no emotional investment between you and me. That's why 1 agreed to do this. And I was really hoping that you would not be ... bizarre (laughter). I was saying, "please don't let her be a space case, I could not deal with that," (laughter). So this is therapeutic for me.

\section{LIMITATIONS OF THIS STUDY}

A transgender person was included in the sample, contrary to the fact that most transgender people do not consider themselves part of the gay community. The lack of information on this group of people makes most researchers leave them out of their studies because of the difficulty of putting them in a category with other research subjects. Therefore, they continue to be a group of people excluded from most research. Mira was interviewed because transgender issues brings a new dimension to black gender roles and sexuality. She also contributed a different perspective on the black gay community, in general, and on the issues addressed in this study, in particular.

Unfortunately, in an effort to limit this research, a bisexual black man was not included in the sample. This would have been an interesting contribution to this study because a number of the men interviewed had had sexually and 
emotionally stimulating relationships with women in the past, but still considered themselves gay and not bisexual. It would, therefore, have been interesting to compare these experiences to those of a person who identified as bisexual. Also, some research indicates that bisexuality might be more common in the black than in the white population (Staples, Masculinity, 89). For future research, including a lesbian black population would also be useful for a more comprehensive study on gender roles in the black community. Black lesbians seem to be even less represented in stucies than black gay men are. Also, some research indicates that lesbians are less accepted in the black community than gay men.

A comprehensive discussion of the possible causes of homosexuality - the nurture or nature question--will not be part of this study, although a brief overview will be included in the analysis on gay identity. Other researchers have collected data on this topic and new discoveries are being made in differences in the brains of homosexual and heterosexual men. The author shares the belief expressed by Dave, age 41: "For me, my perception is that everyone has a certain amount of bisexuality and homosexuality in their potential behavioral make-up."

One cannot write a thesis on black gay men in the San Francisco Bay Area in the 1990s without mentioning AIDS. According to the article "Double Jeopardy" written by Stewart, 23 percent of all gay men with AIDS are black, double what color-blind expectations would dictate (13). Gay and bisexual black males are the populations most at risk for contracting HIV. The questions asked the sample did not contain any questions on HIV or AIDS. This was done on purpose, first of all because a number of studies have been done around HIV and AIDS. Also, it was expected that the issue would surface by itself due to the nature of the open-ended questions. Not surprisingly, all, except one, brought up the subject sooner or later during the conversations. Four of the thirteen people in the sample stated that they had AIDS or had tested HIV-positive. Some of the issues which surfaced regarding AIDS and HIV will be discussed in a separate chapter. 


\section{CULTURAL IDENTITY}

Cultural identity has, for the purpose of this thesis, been defined as the feeling of belonging to a certain group of people. This can be an ethnic group, like the African-American community, or a group formed on the basis of sexual orientation, like the gay community.

We are getting two messages, one of them, which is really blatant is: "You're going to hell for being homosexual/bisexual." The other message, which is sometimes not as blatant as that, is that the lack of discussion about you in your community--the lack of validation and acknowledgement that you exist--also sends a message that you're not good enough. All of that stuff often stands in the way for us to function as a community with support for one another, and to build things which are going to help us.

- Karl, age 31.

The gay community has layers of discrimination. Racism is as alive and well within the gay community as it is in the heterosexual community. There are sections within the black gay community, reflecting the general heterosexual black community, which are called Afro-centric or sebaratist. There is also an organization called Black and White Men Together (BWMT). This organization is often criticized. Most of the people interviewed brought up this name for one reason or another during the interviews. Some people were, or are, members of the organization, while others expressed strong opposition to the organization.

Two of the questions asked of the sample regarding these issues were: "Do you consider yourself as being part of a gay and/or black community? If so, do you see any conflicts in being a black man in a gay community and/or a gay man in a black community? How and why?" The second question regarded partners: "Are you in a relationship right now? If so, describe your partner and 
your relationship. Were you in any relationships before then? What are the ethnic backgrounds of the partners you have had?"

The sample varied with respect to the amount of racism and homophobia they had experienced in the gay and black communities respectively, and, consequently, in their attitudes towards these communities and individuals in the communities. Most people in the sample felt much more a part of the black community than of the gay community. They claimed that the gay community was created for and by white men, with black men being peripheral and invisible. Two people in the sample did not consider themselves part of either a gay or a black community, and they did not have a strong support network in either community. Six people lived in predominantly straight, white neighborhoods. Two people lived in a gay neighborhood, while five people lived in predominantly black neighborhoods. All of the people in the sample had either experienced racism in the gay community, or they claimed that the gay community was racist. At the same time, most agreed that while the black community was homophobic, it was easier for a black gay man to live with homophobia in the black community than with racism in the gay community.

About half the sample had dated mostly white men. Two people had dated black men exclusively. One person had just come out as a gay man at the time of the interviews, and had never had a sexual experience with another man. He self-identified as homosexual, but was still married to, and living with, his black wife. Some men had dated people of different ethnic backgrounds. Four people were in relationships which had lasted more than two years at the time of the interviews. Three of these relationships were with white men. Three people lived with their partners. The remaining people were in and out of relationships and had occasional lovers.

\section{A. PARTNERS AND RACISM}

Racism seemed to be closely associated with choice of partners in the gay community. Some black gay men feel rejection from white gay men, and 
claimed that the gay community was for white gay men only. It is hard for a black gay man to become a respected leader in the gay community, at least without a white lover by his side. Some black gay men are torn between the black and the gay communities, not fully accepted by either. Conrad, age 51 , had this answer when asked about racism in the gay community: "They had a question in one of the biggest gay papers here: 'Do you think there is racism in the gay community?' You could call in your answer. The next week they gave the response, and I could not believe the answer: One hundred percent of the people who responded said yes!"

Most black gay men remain in the black community, often in the closet. It is easier for a black gay man to waik down the streets of a black community and predict how the black straight people there will react to him than it is walking down Castro Street in San Francisco and either be ignored or subject to unpredictable discrimination by white gay men. As Lang, age 52, explained: "I have definitely experienced racism in the gay community. I have woken up the next morning with a white man saying, 'I really must have been drunk, you're black!' "

A number of people claimed that in the gay community racism is closely associated with who chooses what sexual partners for what reasons. A number of people stated that the ethnic background of lovers was often part of a social and political agenda. As Ned, age 37, explained: "One of the undertones, and probably an unspoken rule in the gay community, is that you do not find very many black on black couples, or Asian to Asian couples, or any two people of color together with the same ethnicity. It is rare." Ned elaborated on this concept:

Gays are sexually promiscuous, anything from bondage to $S \& M$ to slave and master kind of thing. I can't get into that. It's like some of the white gays who are into the $S \& M$ and they want to be punished for ever having been related to somebody who might have been a slave holder. That's why they want a big black man to spank them and somehow they end up in a relationship, and I think that is sick. I'm not trying to make up for the world's 
social ills in my relationships, but a lot of people do: "To justify racism, I have a black lover, therefore I'm not a racist," and vice versa.

This was an issue which split the people interviewed: one group was accused of being Afro-centric because they only had black lovers, the other was accused of denying their own identity by having mostly white lovers by their side. Some of the people in the sample preferred white lovers, and expressed a distrust in other black men because of the homophobia they had experienced in the black community.

It is often assumed that gay people are more tolerant of other minorities since they themselves have felt prejudice in various forms. However, this does not seem to be true. Often, the white men who preferred to be with black men were looked upon as having low self esteem, as Lang, age 52, expressed: "I resent Black and White Men Together. The white men in there I would not even ... (laughter). They have the lowest self esteem. What elevates them is being with black men. Then they can feel superior."

Most of the people interviewed had experienced racism in bars in the gay community in the form of being asked for multiple pieces of ID and being subjected to poor service. They also expressed a feeling of being invisible in the streets, media, bars, and general life of the gay community. Some expressed having experienced what Ned called "sexual racism":

There is a group called BWMT that l've never really been supportive of, but I've never been angered by them either. I believe that they do some good work, but I am a black man who likes black men. I'm an educated black man, and I consider myself a decent black man, and I find that the majority of well-educated, decent black men are there swinging in some white boy's arms and it just pisses me off because they will not give me half a chance. There is a lot of racism in that community, but it doesn't always have to do with social racism--it's sexual racism as I call it.

A number of people expressed feelings about what they saw as a lack of representation of black images in the gay press. Karl, age 31, explained: "If 
you pick up any of the gay white press, without any exception, black people are hardly in it at all and, when we are, we are always embracing a white person, or there's a big dick in it to dehumanize us, which also puts out a message that, without a white person in our vicinity, we are not fully at their level."

Some of the people in the sample had negative experiences with other black men, often in the form of homophobia or a gerieral lack of approval. This had led some to chose to live with the racism in the gay community rather than having to deal with the lack of acceptance in the black community. Eric, age 36 , who was still living with his wife at the time of the interviews, explained:

I don't think I would date anybody black. The history with me and black men is negative. My foundation is negative. When I see black men, all I can think about was when I was growing up, and how black boys mistreated me because they misunderstood who I was, from school, and most of my life. It wasn't until I was well into my life that I had what I call a positive experience with a black man, and that was my uncle. That has only been within the past five or six years. Mostly the black gay men that I had seen when I was living in the heterosexual environment were always flaming queens. I'm not attracted to feminine men. I don't care what color they are, the real sissy types are real turn offs for me. I actually prefer men that do not read gay. I especially don't want one dressing up in drag (laughter).

Frederic explained that he had never felt accepted by other black men because he was from the West Indies, spoke with an accent, and had a different culture all together. He joined BWMT in order to meet other black men.

Some people stated that in order for a black man to be in a leading position in the gay community, he needed to have a white man by his side. Karl claimed that most of the black gay men in the white gay community were black men with white lovers, and that that was the only way they were accepted in that community. He claimed that the majority of the black gay leaders had white lovers. 
Some of the people interviewed dated people of different ethnic backgrounds. Conrad had an Asian partner, but his three previous long term relationships had been with white men. Bern, age 30 , had been with men of "every thinkable ethnic background" during the past few years. His one live-in lover had been white. Lang, age 52, expressed having been with men of all colors. He had also been with white men and had experienced much racism: "I have met some men that I have conironted with the fact that they are racist. I cared for them, therefore I confronted them with it." Others, like Ned, would date exclusively black men: "I have only dated black men, but competition is stiff. That doesn't stop me. Black women complain about not being able to find a decent straight black man. Shit, they just don't know you can't find a decent gay one either (laughter)."

What most of the people interviewed had in common was that they had an opinion about the organization "Black and White Men Together." The sample was not asked about this organization, but most people brought the name up while they were talking about racism in the gay community. This organization was formed by white men in the early 1980 s. Some claimed it was formed in order to address racism and bar discrimination in the gay community. Most people expressed negative feelings towards the organization and claimed it was a social sex club, at least as racist as the rest of the gay community. Karl, age 31, who had dated mostly black men, expressed his feelings about BWMT: "BWMT is an organization which was founded by white men who like black men sexually, which does not make you progressive because you want to stick your dick in a black person. Look at what men do to women. That does not mean they respect them, it means they want to fuck." Lang, age 52, who had dated a number of white men, expressed the following:

I left BWiMT three years ago. My lover and I went to their first meeting in 1980. We thought that this would be an opportunity for us to show the gay community that black and white men can get together. My lover was white. We had been together five years then. But all the white men were hitting on him (laughter) ... It's sort of a breeding ground for prejudice. That's really sick, gut-level prejudice. That's what BWMT represents to me. 
Some people expressed the idea that the black community, in general, and the black gay community, in particular, need to stand together separate from the white community in order to build up leadership and validation from within. Others expressed a need for people of all colors to come together to build cultural bridges and harmony. It seemed that most believed in a healthy mix of both of these components:

What's happening now, to a degree, almost by necessity, is that you're getting black groups coming together and forming separate groups. The same thing with Asians and Hispanics. People look at it as separatist, but you have to have a certain amount of it to feel pride and to get self esteem. .... Hopefully, throughout all this, pain will pull us back together and a leader will evolve that can use the same system to make it work for us as a community.

- Conrad, age 51.

We need to have our separate pockets where we can reaffirm ourselves for who we are as we are, but we cannot disconnect ourselves from the human experience. We cannot refuse to take part in the human movement. because that's who we all are. Every human culture has made stupid mistakes, has made horrible, inhumane mistakes. I don't think we should always be separate, but we need rejuvenation space. I'm called a separatist, but I'm not.

- Karl, age 31.

A number of people in the sample participated in the March on Washington, during the time of the interviews. Some people talked about different issues regarding the March, and expressed concerns about the frequent use of Martin Luther King's speeches from the civil-rights March in 1963. They felt that it was inappropriate to compare the fight for gay rights to the long struggle of black people:

I'm really very tired of many gay leaders quoting Martin Luther King. I said to a friend of mine the other day: "Why do these white gay men 
quote Martin Luther King? If people just hopped onto this planet and heard them, they would swear Martin Luther King was a gay white man!" Martin Luther King was quoted more than anyone else on the March on Washington. There are gay heros, but these people are trying so hard to relate the gay movement to the race movement in this country. That's very cute, but they are very different.

- Bern, age 30.

I went to the March on Washington this year ... It seems to me that there had been a greater effort to show more gender and ethnic diversity this time around. .... I'm a little concerned that it's trying to appropriate the sentiments of the African-American civil-rights movement, without first having demonstrated its commitment to equal opportunity of participation without regard to ethnic or racial backgrounds. I must say that racism is alive and weil in the gay community and it bothers me that you have people shouting slogans and adopting the rhetoric and the songs and even some of the imagery, like showing Martin Luther King's "I Have A Dream" speech from the March on Washington in 1963. They tried to make that connection. I should not discourage it too much because, I guess, it could represent, to a certain extent, an effort to become more diverse.

- Dave, age 41.

Lang was one of the organizers of the March, and he was asked the following question: "I have heard some criticism of the fact that there were a lot of siogans used from the black civil-rights movement, and that Martin Luther King was quoted a lot. It has been called hypocritical that the gay movement has taken his words into their mouths. What are your comments to that?" Lang, age 52 , had the following response:

It's because the blacks involved in the planning of it insisted on it being such, and that's why. It's from those who are still resisting the fact that it really is patterned after a civil-rights March ... I think that gay and bisexual people are dealing with racism far better than the rest of the society. In Washington, I could see this in my involvement with the executive committee. There were still a majority of white people there, but there were some large contingents of colored lesbians and gays, more than I've ever seen before. We did extensive outreach. It started with the March committee. At out first meeting in Chicago, a year and a half ago, 
we fought for parity around the national committees. A parity consists of fifty percent people of color and fifty percent women.

I was interviewed a number of times for newspapers and I was asked: "What does this March mean to you?" I said: "It's a civil-rights March. I march because l'm black and because I'm gay. I'm marching to change the rules in the Catholic church" (laughter). So, for all these reasons. So it's not just a gay issue. I think that's what this March was able to do.

Most of the sample expressed opinions about the March on Washington. Some strongly disapproved of the organizer's efforts to compare the gay civil rights movement to that of the black civil rights struggle. Others claimed that the movements were similar because both are fighting for civil rights and because black people are part of both movements.

Everybody in the sample gave examples of racism within the gay community. Most often this was expressed in terms of bar discrimination, the choice of ethnic background of partners, the lack of--and the type of--representation of black images in the gay press, being invisible in the gay community, and the difficulty for a black gay man to become a leader in the gay community. The name of the organization BWMT was often mentioned in connection with racism.

\section{B. HOMOPHOBIA}

Black America tends to be both more and less tolerant of gay men than white America. Among the working class, religion and ignorance dictate that homosexuality is a chosen behavior and therefore subject to moral judgment. AIDS is seen by religious blacks as divine punishment for "abomination." Yet blacks are often less judgmental about individual gayness. The church choir "queens" and the series of same-sex "roommates" are accepted, provided they do not expect explicit validation of their lifestyles. There is a prevalent "live your own life, but don't preach about it" attitude that protects deviance at the price of silent invisibility.

Bourgeois blacks are equally ambivalent. Better educated, they are less prone to cloak their prejudice in biblical or ersatz theory, but they are 
increasingly wary of the impact of the gay agenda, deemed a threat both to black needs and to the growing Afro-centric focus on self-restraint and renewal of commitment to family and community.

- Stewart, 15.

Most people in the sample stated that the black community was homophobic. People disagreed on how homophobic the black community was in comparison to the white community. Some described homophobia in the black community in the form of limited opportunities to become a community leader and get respect in your community if you were "out." Some claimed that this was slowly changing because the church and other institutions in the black community had been forced to open their doors to gay people because they needed their expertise and knowledge of AIDS. Conrad, age 51, who had AIDS himself, had made the following observations:

In a way, AIDS has broken down the walls a bit. For a while, well, still, the black community is more in denial when it comes to AIDS. Still, people who were homophobic are welcoming the experience and the help of black gays and lesbians who have been in this from the beginning and have developed expertise.

An African-American woman who ran for Supervisor had a black gay man as her campaign manager. This gave him an "in" to black political organization, so now we're getting more of that, where black gays are accepted into the African-American political scene. Black gay people are now coming into the black community as known gays with a political agenda both as gays and blacks. The black community knows that this connection with the gay community, politically, is good because the black community needs us.

Some people also claimed that the homophobia in the black community does not have deep roots. Families will always welcome their children back home, no matter what, and the black community is used to standing together through difficult times. Some also referred to the fact that gay people had their place, both in the black community, in general, as entertainers, and also in the black church choir, as Eric, age 36, expressed: 
If you go to your traditional southern Baptist church, a black congregation, you have queens running all over the church, especially in the choir. For some bizarre reason, it's acceptable on that level. Some of it is religious and a whole lot of it is stumbling, the whole idea of family. It takes a man and a woman to reproduce life, so if you're gay and you are a black male, then you will not have children. Then, what will happen to the race? We will not have any more black children! So, it's that and the whole idea that the white man put this on us.

Some of the people in the sample stated that homophobia in the black community had a religious foundation. Some claimed that the black community looked at homosexuality as a white man's disease, and that people in the black community rejected homosexuality because they rejected white people. Karl elaborated on what he saw as some of the religious dynamics of homophobia in the black community:

A lot of the black people who are fighting for gay rights are acting out against the black community. They don't have the context. They don't understand that homophobia did not come from inside the black community and went out, it came from outside and in. And ironically, they go into a racist community to fight the black community on homophobia. But those white gays are a lot more connected to the source of the homophobia in the black community than the black people are, in terms of it's origin. The homophobia came into the black community through Christianity introduced by white people. I'm talking about origin here, not necessarily current systems, even though there are some current systems, too.

Eric grew up being told that homosexuality was something that did not exist in Africa. He was told that it was something that was put on the black man in slavery, but he did not agree with this. He stated that because so many people in the black community believed this theory, they rejected homosexuality simply because they rejected white people. Bern, age 30 , disagreed that the black community was more homophobic, and expressed the following: "I do know that most black gay and lesbian people I know can go home again. When I look 
at family structures, the black family has their rifts and all of that, but I know few black gay men and lesbians who do not have a good relationship with their parents." Some referred to traumatic experiences of homophobia in the black community during their childhoods, in terms of verbal, physical, and emotional abuse, which led to a total rejection and fear of the black community later in life.

Some described indirect homophobia in the black community in terms of limited opportunities, rather than aggressive opposition. Gay people were not taken seriously in the black community, and they would not be given the respect of a community leader. Black communities have a long tradition of offering high respect to talented singers and performers. Gay people were accepted as such as well, but they still could not serve as role models for their communities. Conrad, age 51, talked about his childhood in the South:

There were these sissies who were known to be gay. You always have these kind of people who don't care what people think of them; they are who they are. I became befriended by one of the main ones of these people. He sort of educated me as a young gay man. You could go and have a drink with his friends and the black community accepted it.

Lang, age 52, talked about his experiences as a black gay man while in Vietnam. He had this to say about the ban on gays from the U.S. military:

We built two orphanages while we were in Vietnam. There are so many half American babies there. So many beautiful babies, it's just amazing. One thing that really angers me about the military ban is that we have all these things focusing on gays' and lesbians' behavior. What about the heterosexual behavior? They have left babies all over the world after being there.

Homophobia in the black community was often experienced in the form of limited opportunities for black gay people to become community leaders and to gain respect. As a result, many stayed in the closet if they aspired to political or social careers in their communities. However, there seem to be some signs of 
change in this regard. As Conrad, age 51, explained, "the black community is beginning to open its doors to black gays because their expertise is needed in the fight against AIDS."

\section{ROLE OF WOMEN}

Women did play a role in the lives of most of the people in the sample. Some had had female lovers in the past, and most had women as close friends at the time of the interviews. Most people mentioned being close to women in their families, either mothers, sisters, or other relatives.

The following question was asked the sample regarding women: "Can you tell me what role, if any, women play, and have played, in your life?" Most people had women as close friends, like Bern, age 30, explained:

There are lots of women, lots of women in my life. The two biggest female influences in my life are my mother and my best friend. And my sister too. These are important women in my life. It doesn't seem like a very healthy balance what I have right now. I'm not saying I need to have this quota system (laughter). But there is something artificial, even when you're in this area, for a gay man not to have relationships with women.

Most people mentioned their mothers as important women in their lives, and often other family members were mentioned as well, like grandmothers and sisters. Karl, age 31, expressed this about his mother:

My mother was a direct symbol of what women go through and how women are brutalized, and how unfair it is. Learning about what women go through nationally, as well as globally, it enrages me and upsets me. So, from a very young age, I was a ... what some people might define as a feminist. I'm also very, very comfortable with my own feminine side, or my ability to be feminine. I have a lot of respect for what is feminine, which often includes women, but I've had a few traumatic situations that 
have had an impact on how I deal with women. I've had some traumatic experiences with a number of women.

A few expressed limited contact with women, like Frederic, age 60: "Women don't really play a part in my life now, except my daughters. I never really had many women in my life, which is funny because my ex-wife used to accuse me of cheating on her, and I never did (laughter), man or woman." Others, who had known they were gay since early in life, found women frightening. Conrad, age 51 , avoided women until he was in his early twenties. He later in life developed close friendships with women: "I now have lots of women friends; gay women, black women, all kinds of women friends. My women friends are very important to me. In some ways I feel that my life was lacking something when I was avoiding women. Now I feel that that part is there and I value those friendships."

In summary, people in the sample had different experiences with women. About half the sample had had sexual experiences with women in the past, often in the process of establishing a gay identity. Some had been through periods in their lives when they avoided women because women represented a threat to their gay identity. Most people had close friendships with woman at the time of the interviews, and talked about being close to female members of their family as well.

\section{SUMMARY OF FINDINGS}

Most people in the sample had experienced various degrees of racism in the gay community and homophobia in the black community. Identity and involvement with either community varied among the people in the sample. This identity was often closely associated with the ethnic background of the person's lovers. Often people who identified strongly with the black, rather than the gay community, would chose to have only black lovers. It was stated that the only way for a black gay man to become a leader in the gay community was 
to have a white lover, while the only way to become a leader in the black community was to stay in the closet.

Homosexual men have historically had their place in the black community, in the church choir and as colorful characters on the streets, but they have never been given respect. This is slowly changing because the black community now needs the expertise of gay men in the fight against AIDS.

Women seem to play an important role in the lives of most of the men in the sample. Some went through periods in their lives when they did not have women friends, but most were, at the time of the interviews, close to a number of women. About half of the sample had had women as lovers, and most people mentioned being close to female members of their family.

\section{E. ANALYSIS}

Black gay men often feel that they do not belong in either the gay or the black community because of racism in the gay community and homophobia in the black community. The results in this section were greatly influenced by the age of the sample. Had the sample been younger, the results would not have included personal experiences from the civil rights movement, but probably would have reflected more of the reality of young black gays today. The 1990s are very different times for young black gay men to grow up in, than the $1950 \mathrm{~s}$ and 1960 s were. It appeared that people in the sample had become a bit more willing to accept differences, the older they got. This was reflected both in the attitudes towards white people and in the way people looked at the merging of the black and gay movements. 


\section{Partners and Racism}

if you can ascend / to the top of the whitest strata and rationalize me out of existence / remember what $i$ told you you will always be / just another faggot like me by the same reasoning process / that reduces me to being just another nigger

- Bean in Saint, The Road, 14.

The people who lived in predominantly black neighborhoods seemed to be the ones dating mostly. or only, other black men. These people also expressed experiencing more racism in the gay community and from white straight people than those people who lived in white communities and dated white men. Also, the intensity of how each person experienced racism could often be related to age and where the person grew up. Those who participated in the civil rights movement in the 1950 s and 1960 s viewed racism from a historical perspective, tended to have had mostly white partners, and expressed a need for black and white people to fight racism together. They also seemed to be more open to correlating the gay movement with the black civil rights movement, and did not express a strong opposition to using Martin Luther King's words in the March on Washington.

Black gay men were still subject to discrimination in the gay community, but it was less blatant than it used to be. In the 1970 s and 1980 s a black gay man often had to present multiple picture IDs before entering a bar in the gay community. At the time of the interviews he was more likely to be ignored, and had little chance of becoming a leader in the gay community.

Racism in the gay community reflects the rest of the society. The entire gay movement was formed by white men who brought their prejudices with them. Prejudice does not just come from one source. There are layers of prejudice and discrimination in the gay community. People in the sample addressed their issues and political agendas by giving very specific examples of how they and the people that they were affiliated with were hurting because of the 
discrimination they had to deal with. Then they ironically stated that they had no space for black gay men who either affiliated with different organizations, chose different partners, dressed differently, identified differently, had different agendas, or lead different lives altogether. Some people expressed negative feelings towards people who affiliated with BWMT, people who chose white lovers, "flaming queens," feminine men, and black gay men who lived in the gay community.

The ethnic background of partners and lovers seemed to be very important in defining oneself and others in the gay community. It was a subject talked about by most of the people interviewed. Different views were expressed by the sample regarding racism in the gay community and the choice of partners. Most people, including those with white partners, talked about the often unhealthy dynamics of interracial relationships, or the motivation behind choosing a sexual partner with a different ethnic background. People in the sample often believed that white men chose black partners because of the sexual mystique associated with black sexuality, and because of the historical taboo of sexual relationships between black and white people. It seemed that people who themselves had white lovers, either at the time of the interviews or in the past. were able to distinguish between healthy relationships between a black and a white person--a relationship based on mutual love and respect--and those based on unhealthy motives like sexual exploitation. Those people in the sample who had had only black lovers tended not to make this distinction, and described all these relationships as being based on sexual exploitation.

Some claimed that most white gay men who are with black gay men are men who feel inferior in a white context and therefore seek out a black man to feel superior in their relationships. According to a study by Staples, an interesting characteristic of the life-style of black gays is the extent of their involvement with whites. Over two-thirds of the black male homosexuals in his study said that half of their sexual partners had been white. One black gay man declared that the majority of whites who are homosexually interested in blacks are misfits, that they desire a black mate oniy because they sense an identity between their own feelings of inferiority and the myth of black inferiority (Staples, Singles, 202). 
Some of the black gay men in the sample were not comfortable with the image of themselves being with another black man, often because of experiences they had had with black heterosexual men and homophobia while growing up. This was most clearly expressed by Eric who had suppressed his homosexuality for many years and was married and had three children. He had an image of all other black gay men as being extremely feminine. Historically, these had been the only visible gay images in the black community, since most black gay men have stayed in the closet if they have chosen to remain in the black community. Eric, who did not like feminine men, had therefore written off all black men as either being homophobic straight men or feminine gay men. Other people in the sample explained this same concept. The absence of a greater variety of gay images to identify with left young black gay people without role models in the black community. Some were therefore drawn toward the gay community, but most continued the black gay tradition of staying in the closet in the black community.

When examining the attitudes expressed regarding the use of black civil right's slogans in the gay civil rights movement, age influenced how the sample viewed this. The older the participant, or the observer, the more tolerant his attitudes were in accepting the two movements as inter-changeable. This difference was most clearly expressed by Lang, age 52, who was one of the organizers of the March on Washington in 1993, in comparison with what Bern, age 30 , said. Perhaps those people who lived through the civil rights movement from its beginning had developed more flexible attitudes because they had experienced it first hand. The younger population appeared to be more reactionary, while the older population seemed to be searching for harmony.

The March on Washington created strong emotions in some of the people in the sample. Both negative and positive feelings were expressed over the fact that the leaders of the gay movement use slogans from the black movement, in general, and the words of Martin Luther King, in particular. Some people expressed strong opposition to trying to create the same sympathies for gays as 
for blacks. The arguments were that gays can choose to hide their sexual orientation if it is of benefit to them, while black people have suffered from slavery for centuries. Others claimed that both movements had to do with basic civil rights for all people, and they claimed that the only way for some people to understand the gay struggle was to compare it to the black struggle.

Looking at Martin Luther King's famous "I have A Dream" speech from 1963, one can only guess at how inclusive his speech really was when it came to gay rights (Sitkof, 163):

I have a dream that one day even the State of Mississippi, a state sweltering with the heat of injustice, sweltering with the heat of oppression, will be transformed into an oasis of freedom and justice. I have a dream that my four little children will one day live in a nation where they will not be judged by the color of their skin, but by the content of their character. I have a dream today.

An interesting question arising from this is "what if one of these little children were to come home and tell dad that he was gay?" Would dad then still stand by his words that all people should be judged by the content of their character? After all Martin Luther King was a Christian Minister, and the black church has not historically been a supporter of gay rights.

A number of people in the sample expressed concerns over the lack of black images in the gay press. The few black images found were most often in a sexual context. It was easy to find sexual black gay images in which only a penis is shown, but harder to find a black gay man in pictures portraying a spokesperson or leader for gay rights. Some people claimed that for a black gay man to be acknowledged and respected in the gay community, he needed to have a white man by his side. This is reflected in the many images one could see in the gay media, where black men often are portrayed together with white men. One can easily pick up copies of the general gay press and get the impression that all gay people are white. When black images are presented it is often only in a sexual context. or with a white man by his side. The gay media of 
the 1990s is better than it was in the 1970s and 1980s, but one is more likely to find real, whole black people represented in the gay alternative press, than in the general gay media.

Experiences in childhood and early adulthood often determined how people in the sample dealt with their homosexuality later in life, in relation to the black and gay communities. In some cases, those who were able to explore their own homosexuality early in life, had integrated race and homosexuality into their identity and were often involved with both black and gay political and social agendas in the community.

\section{Homophobia}

I hate you as much as I love you Black man

Back in grade school, you called me: / "Sissy!" / "Pussy!" / "punk!"

By the time I got to junior high, you added: I "Fag!"

I called you my father, / and you stood me up time after time.

I called you my lover, / and you pushed me out of your bed,

I called you my teacher, / and you didn't want me near you.

I called you my friend, I and you hurt my feelings for fun.

- Charles in Wilson, et al., 129.

The issue of homophobia in the black community is hard to pin down and define. The quotation from the article "Double Jeopardy" by Stewart, used in the beginning of the findings section, illustrates this very well. The black community seems to accept homosexuality and gayness, as long as it is not talked about or demonstrated. Therefore, black gay men are, to a certain extent, accepted in the black community, but only if they stay in the closet. Homophobia is clearly present if a person with an open gay agenda wants recognition from the community. On the other hand, if a person is a "good community member," the community will chose to ignore what he does after dark. This is the double standard practiced by the black community. Therefore, as Stewart points out, the black community is both more and less homophobic 
than the white community. This contradiction needs to be kept in mind through the following discussion.

There are many different views on homophobia in the black community. The church plays a central part in the lives of many black communities, and much of the homophobia has its roots in what the black Ministers preach. Despite this, homophobia within the black family seems to be less than is the case with white families. The black family has historically pulled together through difficult times. This has created a strong sense of family, and very few black gay people are totally rejected by their families after the fact of their homosexuality is known.

Most people in the sample stated that the black community is homophobic. However, no indication was found that the black community is more homophobic than the white community. This might be influenced by the fact that the white gay population often is part of a white gay community, while black gay men often stay in the black community.

As Karl explained, homophobia in the black community can be as blatant as being told that you will go to hell or being beaten up because you are gay. More often, it is in the form of a lack of opportunity to become a respected member of the community and ignoring and never affirming gay people for who they really are. A number of people in the sample stated that most black gay men live in the black community, often in the closet, rather than having to deal with the racism in the gay community.

Some people claimed that the homophobia in the black community stands in the way of the community bonding together and fighting the many challenges faced by the black community together. Many talented black gay people are denied leadership roles in their communities because of their homosexuality. Conrad pointed to the fact that the black church, and the community in general, are opening up more and more to gay people because they need their expertise to combat AIDS. As more black gay men apply their knowledge and resources to AIDS related projects in the black community, a widening acceptance of gays in the black community may result. 
Another interesting issue was the amount of family support most of the people in the sample felt that they and other black gay men had in comparison with their white counterparts. Most people in the sample expressed that while they may have gone through a period in their lives when they were not close to their families, a time often connected with their family learning that they were gay. they were very close to their families later in life. Some claimed that writing off a child because of homosexuality was a white concept, that you do not find in black families.

Homophobia in the black community has many contradicting aspects to it. The black community, or at least the black family, is seen as less homophobic than its white counterparts. At the same time, many examples were given to show that the black community is homophobic. Kinsey's report also found that black heterosexual men are more comfortable around homosexuals than white people are, and that they do not perceive them as any kind of threat to their manhood. As Staples writes: "That is why they are not isolated from the black community." (Masculinity, 89). A few people in the sample stated that one of the reasons for homophobia was the fact that the black community wanted black people to have children so that the race would continue. This is a combination of a religious foundation and the importance of the family in the black community. However, this strong sense of family makes it easier to overiook a man's sexual activity with other men if he has a wife and children at the same time. This has the function of keeping and continuing the family and being able to brush the gay activity under the rug.

According to Clarke's article, one should not have to choose one or the other:

Black family lifestyles and homosexual lifestyles are not antithetical. Most black lesbians and gay men grew up in families and are still critically involved with their families. Many black lesbians and gay men are raising children. Why must the black family be so strictly viewed as the result of a heterosexual dyad?

- Clarke, 200. 
Some people in the sample, like Eric, had been told in school that homosexuality was something that did not exist in Africa, that it was something put on the black man in slavery. It is difficult to trace black homosexuality historically back to slavery or to roots in Africa. According to Staples:

\begin{abstract}
Homosexuality is the most difficult behavior of blacks to trace historically. Wherever social contact between persons of the same sex has existed, there has probably been some homosexual behavior. In pre-colonial Africa there was traditionally a division of labor, separate initiation training for males and females, in addition to economic and sociopolitical associations organized along gender lines. The practice, for instance, of some African tribes of sending young male children off to separate compounds may have produced some homosexual behavior. Such practices are rarely noted in the literature on African society.
\end{abstract}

- Staples, Masculinity, 87.

Anthropologists have found various forms of homosexuality and gender roles in tribal societies, and as Staples stated, one can assume that homosexuality takes place within most social structures, historically, as well as today.

Some theories exist stating that homophobia in the black community is rooted in the image of the black macho man and his sexual mystique (Staples, Masculinity, 87). The macho image was created during slavery when all power was taken away from the black man. Marriage between slaves was not recognized by the slave owners, and the black man was not even in a position to protect his female partner from sexual assaults by the white man. Because of this, the black man created a macho image to compensate for his lack of power. This image is threatened by homosexual men. Homosexuality denounces the macho image of the black male, and machismo plays an important role in the black community, historically and at present (White, A: 4). This supports the theory that men who have not integrated their feminine and masculine selves, and fear their own feminine aspects-often because they associate femininity with weakness--react more strongly to femininity in other men. 
The black community's views on homosexuality are complex. They reflect a willingness to overlook covert homosexual activity if the individual will otherwise be a contributing member of the community. Homophobia in the black community, and in society at large, can, to a large extent, be traced back to American fundamentalist Christianity and its many taboos related to sexuality. As Eric explained, some also claimed that homosexuality is associated with the fear of a decline in child birth and an eventual extinction of the race. As the black community opens up to the leadership and expertise of gay people in AIDS-related activities, the black community will experience the value of talented black gay men in their communities, leading to a greater acceptance of homosexuality. Resourceful people will be able to actively participate in community life and gain respect from the community, and young black gay people will have strong gay role models right in their own community. The end result may be a less painful road for young black gay men in exploring and establishing their own gay identity.

\section{Role of Women}

Black male adolescent survival in a ghetto context made me realize the necessity of having a girlfriend, a female I could be seen walking home after school. It would be my luck to date girls who were "good," girls who were not going to experiment with sex beyond kissing and fondling, and even that was often only tolerated at a minimum if tolerated at all.

- Hemphill, Ceremonies, 102.

Most of the men in the sample had many important women in their lives and were very close to their mothers. With only two exceptions, everyone in the sample expressed very strong emotional ties to their mothers, and described their mothers as being very strong. Most people also referred to other female members of their families, like sisters, aunts, and nieces. A number of people said they had very high opinions of women in general, and some made references to women they respected highly as community leaders. Those who 
considered themselves activists often had close women friends they associated with as a result of their political and social involvement. Those who had gone through periods in their lives without much contact with women said they had felt that something had been missing from their lives at those points.

Most of the people had also had women lovers in the past. A number of people claimed that it was easier for a gay man to be close friends with a woman than with another man because the sexual intentions between a gay man and a woman would never be questioned. Staples' findings'support this : "It's worth noting that only one fourth of the black gay males said that all their friends were men. The other gays probably constitute a large proportion of the platonic male friends many single women have." (Black Masculinity, 92). No indication was made of a difference between black and white behavior in this regard. 


\section{DEFINING GAY IDENTITY}

There are some people that I have met in the gay community who have always been out. They have never been anything but a gay person. They have never been with a woman, if it's a gay guy. To me that is a little bizarre (laughter). But, I sort of kind of understand it. That's the kind of person who was comfortable with who he was from the onset. Some of us don't get there that way. I have never met anybody black like that, who was always gay, and never functioned as a heterosexual. Most of the people that I have met that have done that have always been white, not AfricanAmerican.

- Eric, age 36.

Some claimed that black men were more likely to have had sexual relationships with women before they identified as gay, rather than assuming a gay identity early in life. A number of people stated that they had gone through periods in their lives when they identified as bisexual. This correlates with Kinsey's report which found that blacks were more likely to be bisexual, rather than exclusively homosexual (Staples, Masculinity, 89).

How do black men come to terms with being gay? It was a very different process for each individual. Two people in the sample had been or were married and had three children each. Most people had had relationships with women in the past. Some had had very loving and sexually stimulating relationships with women. Gay identity can be conscious in a person from very early childhood; it can be a political or social decision; it can be something that has always been there but repressed because of social conditioning; or, as with Ned, age 37, it can be discovered by accident:

Two weeks prior to my wedding date, my father and my best friend threw a bachelor party for me. A friend of mine decided that I needed a final piece before I got married, so they started to collect money for this prostitute. Two of them left and they came back. By that time I had had a 
couple of more drinks, so I was really feeling ok. I don't think I was seeing all that well either. It was not a joke, they seriously thought they had picked up a prostitute, but they had taken back a drag queen. I didn't know anything. She kept the lights off, and I'm suppose to just lay there and be the king since this is my night, so she's suppose to do all the work. So I'm laying there and I'm being king and I'm feeling good. All of a sudden I'm like asking myself what that is that keeps hitting me in my stomach. I look down and I see this penis going bang, bang, bang in my belly and I'm going ahhhhh. I found it did not turn me off as much as I thought it would.

How and why then does one come to identify as gay rather than as bisexual? The question asked of the sample was: "Tell me something about how you came to terms with being gay during your childhood, adolescence, and/or adult life. If you consider yourself out, can you tell me something about coming out as a gay man?"

\section{A. CHILDHOOD AND ADULTHOOD}

The sample responded differently to the question on defining gay identity. Lang, age 52, knew from an early age that he was attracted to men, but he did not feel comfortable with the concept of "discovering" gay identity: "I'm asked the question many times when I discovered that I am gay. I don't think that one discovers that. I think that one starts to accept it. So I knew that I began to accept something different in me at a very, very early age ..." Conrad, age 51, knew that he was gay by the time he reached jr. high school. He was concerned about being identified as gay because he did not like to play sports, and was a cheerleader. Dave identified with the gay community by the time he was 24 , after having had a number of relationships with women. He felt he had very little in common with straight men: "I did pursue a gay life style because I had all these other indications apart from sex that were stronger than my identification with women. So it was a political and a social choice for me." Eric, age 36, always rejected being gay. He was called a fag at age 13, and was so scared by that experience, that he used the next 20 years trying to disprove it by getting married and having children. At the time of the interviews 
he had just recently come to terms with his own sexuality and had come out to his wife, but had not had any homosexual experiences.

When Lang, age 52, was asked about what he remembered about his childhood, he had this response:

I remember being 7 very well because that's when I had my first drink of alcohol. Also the fact that at 7 I knew that I was different than the other kids in the community. I grew up Catholic. To give you a little background as to why I remember this so well, for the past nine years I have really been working on my own recovery process. I am a recovering addict and alcoholic. On June 17 it will be nine years that I have been clean and sober and I still can't believe it. The reason why my childhood is not so much painful for me today is because I have learned to live with the pain, through the process of twelve-step. The twelve-step is really an incredible part of my life. I really like to emphasize that. It's the reason why I'm alive and well today. I know that I would not be if it was not for that program.

A stereotypical assumption of gay men is that they did not participate in sports and other rough, masculine activities during childhood. Not everybody in the sample reflected this stereotype, like Lang: "I did not grow up being a sissy. People think that all gay people grow up being a mother's boy. That's a bunch of baloney. I was good in sports, I was popular with girls, and girls liked me because I never tried to go any further (laughter)."

Some of the men describe their first sexual experience with another man:

When I was 10 or 11, I can remember for the first time having sex with another man, my cousin. My cousin and I were lovers. The girls were just crazy about him. He could have any girl. He used to ask me to double date, and then in the end he and I got together. All my sexual experiences while growing up were with bisexual men, so I understand bisexuality. I've never been ashamed of being gay. 
My first homosexual experience was when I was a child and just going through puberty. That was very difficult because ... the experience itself was beautiful, my best friend and I sort of discovered this aspect of our changing physiology. We explored, and we got a little reckless one might say, so we got caught. I was maybe 10 or 11 . All through college my experiences were the sort of, "boy did I get drunk last night," where you actually got so drunk that you could rationalize what you had done the next day.

- Dave, age 41.

When I was about nine or ten I got into sexual play with friends, and it was pleasurable. By the time I was 13 , in junior high school, I realized that I did not have attraction for girls. The two friends that I played with sexiaally didrit turn ouit to be gay. For them it was just a sexual game among kids. I enjoyed it and continued with other people at other times.

- Conrad, age 51.

Some people grew up without having any gay role models, so the sexual exploring was done on their own, usually in deep secret:

At 13 or 14 I became actively gay, sexually, and started seeking sex partners. What I did was to go over to the white community and seek sex partners. It was kind of fascinating, and a little bit dangerous and exciting, that's why I did it I guess. .... I would go to the white community because I knew that if I played around too much in my own community, the black community, where everybody knew everybody, everything would come to light. So for a few years--those early years--1 would go over to the white community.

- Conrad, age 51.

By the time I was 14 I went to gay bars. There was this bar where all the black gays, drag queens and prostitutes were hanging out. They were all friends of mine and it was just a wonderful life. I don't tell about this very much, but when I lived down south I used to hustle. I got very good money. The problem was that I had to hide it from my grandmother and my uncles. When I left that place I had close to $\$ 3,000$ that they didn't know about. There were lots of seamen coming in there and they paid very good money for sex. 
There are also some things that might sound unhealthy when I look back upon them today, but they were very healthy to me then. I had an uncle who was gay. We grew up in a very co-dependent society where the women and the children took care of the drunken men on Fridays. They had worked all week and that was their reward. In the middle of where we lived there was this bar which was owned by another uncle. I grew up in this area where my father was a jazz musician. When most of the gigs were over they would come back to my uncle's bar, people like Dinah Washington and Billie Holliday. Louis Armstrong and my uncle were very good friends, so people like that.

So when the gigs were over we used to help my father and various other men home who were drunk. My uncle always lived by himself. I used to help him home too, and I used to help him get undressed. He would pretend that he was drunk and what have you. He would get aroused and that would excite me. I used to play with him, thinking he would not be conscious enough to know the next day. Now I know that he was not really sleeping or anything like that. In some ways it frightens me to think that I could have been caught, knowing the background of black men. If he was not responding to me and slapped me and called me a sissy and a punk and all of those things, that would probably have been a dramatic period in my life.

- Lang, age 52.

A number of people expressed having had their first homosexual experience with their cousins when they were around ten years old. The level of acceptance of one's homosexuality early in life varied greatly among the people in the sample, and so did the process by which they came to terms with being gay. Two people in the sample stated that their mothers had hinted to them that their father had been gay as well.

\section{B. COMING OUT}

For some people, coming out was a long process, which seemed to be harder the older the person was. For those who had dealt with their homosexuality from an early age, coming out was just an extension of who they were. 
I never came out. Even growing up, among lots of cousins and what have you, I always made my sexuality fit in. I was pretty much a leader, and I knew how to get those other guys aroused. I would get pictures of naked women, but $I$ always made sure to have a picture of a man there too, not just the woman (laughter). So while they are focusing on the woman, I'm focusing on the men. I have always known that I'm gay.

- Lang, age 52.

I moved out on my own into a neighborhood that was heavily gay, and even my mother knew that. By then I had come out to her and she had sort of ... if not given me her blessing, at least her thing was that, as long as you keep this facade of being a moral and decent person, then she did not think that I should, in any way, feel ashamed of being gay. She knew a number of people in church that were discreet and that had been living with the same person for many years.

- Dave, age 41.

I've been kind of a trend setter in my family, the little trouble-making kid that does not take shit, not even from nis parents or his family. I've been quite outspoken about a lot of things in my family, so it's made it ok to be certain things in our family, and gay is one of those things. When I came out a lot of people in my family came out. It's ok to be gay in my family, but they don't like lesbians. It's about a dozen of us out. They all came out about the same time. There are quite a few more that have not come out.

- Ned, age 37.

It was not difficult for me to come to terms with my homosexuality. I was close to 50 at the time. I know that one of the reasons why I went ahead with it was that if you're gay you might as well go ahead with it and let it be. I never had any feelings of guilt or any other difficult feelings. When I realized that I was gay, my main concern was my family, my son, and my oldest brother.

- Frederic, age 60.

The process of coming out was hardest for Eric, who had just come out to his wife. This was the topic he talked most about during the interviews, because, at 
the age of 36 , he was in the process of dealing with not just his own sexuality, but also his marriage and children:

My wife had a strong reaction when I told her I'm gay. She cried and we rolled on the floor and ... it was so hard. I didn't want to hurt her but I didn't want to lie to her either. I told her after church that Sunday. I had decided in my mind and in my heart that I was going to tell her that day. So I wrote her (laughter). I wrote her a four page letter to set the stage. What I wanted to do was to divert some of the guilt that I knew she would ultimately feel, and to tell her that what I was about to tell her had nothing to do with anything she did or did not do, and that she could not have not done anything in any other way and this not to be the fact. I wanted her to know the truth that I'm gay. It was the last thing I said in the four page letter. And then we talked about it and cried.

I haven't come to grips with my own discoveries of who I am sexually, and this has everything to do with why 1 am not sexually active. Within the gay community itself there are no support mechanisms for people who are coming out, and I think that the older you are the more difficult it is to come out, especially when you have a history like mine with 18 years of marriage and three kids.

There are few support networks in the gay community for those who are just coming out, except for those who have the support of their families. For some people in the sample coming out had been a long, and sometimes painful, process. For those who had dealt with their homosexuality early in life, coming out had been simply the process of the people around them finding out that they were gay. These men just lived their lives and did not try to hide their homosexuality.

\section{SUMMARY OF FINDINGS}

Some of the people in the sample claimed that most black gay men went through a period when they functioned as a heterosexual person, and that it was more likely for a white person to have known all his life that he was gay. Despite this assumption, a number of people in the sample had known that they were gay since they were about ten years old. Others went through 
heterosexual periods in their lives, while some dated both men and women for a while. Most people had received a negative response initially from their parents, but had eventually reconciled. Some had had their first experiences with cousins, and one person with his uncle.

\section{ANALYSIS}

How do people come to terms with being gay? It was a very different process for each individual in the sample. One person was married and another one divorced, and they both had three children. Most of the people had had relationships with women. Some had had very loving and sexually stimulating relationships with women. How and why then does one identify himself as gay, rather than as bisexual? Gay identity can be conscious in a person from very early childhood; it can be a political or social decision; it can be something that has always been there but repressed because of social conditioning; or, as with one person in the sample, it can be discovered by accident.

\section{Childhood and Adulthood}

When I was 10 years old, I asked my mama while she was making potato salad:

"Mama, what's a homosexual?" She said: / "It's a man who likes men." "What's a lesbian?" / It's a woman who likes women." "What makes them like that?" / "I don't know, son. Nobody knows. It's a freak of nature."

When I was 14, I heard / her say to my stepfather:

"We can't go nowhere / without you winkin' and blinkin' and makin' advances at other men. I see you.

I'll never trust you as long as you got / a hole in your ass."

- Langley in Wilson, et al., 88. 
The biggest influences for the people in the sample when defining their gay identities were age, the social environment, the period of time in which the person grew up, and personality. Personality played a significant role in how the people in the sample went about exploring their own sexuality. Some people were assertive, exploring, manipulative, and strong minded from early childhood. People in the sample who had those characteristics early on, seemed to have been able to explore and live out their sexuality without much self doubt. Others, who had a more careful way of going about things, were more easily scared and influenced by the responses of others, and, if subjected to homophobic comments early in life, they were more likely to suppress their sexuality for years to come. Some people had had a strong sense of who they were from a very early age, while others took the long way and found out pieceby-piece. One can find these same variations in heterosexual people. Some people begin having sexual relationships early in life and might continue to have many sexual partners throughout their lives, while others are more reserved and shy when it comes to exploring their sexuality.

Some people grew up in environments that encouraged or allowed a young person to find his own ways, while others grew up in a more closed environment. Examples of this were Lang, age 52, and Karl, age 31, on one hand and Frederic, age 60 , and Eric, age 36, on the other. Lang seemed to have had a strong will from early childhood, and was able to manipulate his environment into fitting his own homosexuality. He grew up in an environment filled with musicians, where the men often got drunk and homosexual activity at night was chosen to be forgotten the next day. He hustled on the streets for a period of time, earning good money by having sex with sailors from all over the world. He later went on to have relationships with men of all colors and considered himself an activist with both a gay and a black agenda. Karl was a very strong, independent man who had always felt comfortable with his homosexuality and had integrated this part of himself into his identity early in life. He experienced racism early on, when he came in contact with the gay community as a young man, and had since functioned as a gay man totally in a black community context. 
Eric, on the other hand, was once called a sissy by other black men when he was in his early teens, and became so scared that he used the next twenty years of his life attempting to disprove this. He got married and had three children. He lived in a white neighborhood, worked in a white business environment, and was unable to picture himself with another black man. He was just beginning the process of coming out at the time of the interviews. The situation was similar with Frederic. He was a shy boy who mainly stayed to himself. He went to predominantly white schools, and dedicated his time to studying to become a doctor. He was never very social, and was still not a man who experimented a great deal with his life. He finally came to terms with being gay after his marriage had ended and he was close to 50 . These examples indicate that factors such as personality, environment, and experiences early in life play an important role in how comfortable one is with one's own sexuality. It also indicates that the process of defining one's own gay identity is a unique experience for each individual.

Eight of the thirteen people in the sample were teenagers during the 1960 s and early 1970s. Most of these people started exploring their sexuality during an era when free sex was high on the agenda of young people. This must have influenced the sample a great deal. To explore one's homosexuality during a period of time when young people focused a great deal of energy on breaking down the sexual taboos of their parents, rather than in the present time when homosexuality is more frequently associated with AIDS than with liberation, is likely to make the process of accepting one's own homosexuality easier. Eric, who was in the process of dealing with his homosexuality at age 36 , was an exception.

However, there was no indication that the three people in the sample who were too young to have been teenagers during the 1960s had themselves more problems with their homosexual identity. It is interesting, however, to note that Oscar, age 23, who was the youngest person in the sample, was very involved in different support networks for young, gay people, and was involved in AIDS related work, as well. Bern, age 30 , was also involved in AIDS related work, and Karl, age 31, had started up a support network for people of color with 
different sexual orientations. The involvement of the three youngest people in the sample in AIDS-related work and sexual identity networks might, to a certain degree, reflect the more difficult task of identifying oneself as gay in times of AIDS. In spite of this, it must be noted that most of the people in the sample had been, in one way or another, involved with AIDS-related work because they were contacted as potential interview subjects through organizations dealing with AIDS-related work. Still, it can be said that, to a large extent, the older people in the sample were busy fighting for black and gay civil rights rights at political and social levels when they were younger, while young, black gay people today are more involved in fighting for the survival of black and gay people.

Some people believed that most people are born bisexual, or with a bisexual potential. About half the sample had been with women sexually. Some had sexually stimulating relationships with women, like Bern, age 30: "I had a female lover for a long time and I think that played a significant role in not defining my homosexuality earlier, because we did have great sex together. It felt very natural and good to be with her, so it was more difficult for me to say that 'ok, I'm gay.' " Bern explained that he took a long period of time to discover his sexuality. After he broke off the relationship with the woman, he began comparing his reactions to sexy men walking down the street to how he reacted to attractive women. Only then did he begin to realize his homosexuality. He was finally able to say "I'm gay!" after he had fallen in love with a man and had a romantic relationship with this man. He explained: "I can always have the appreciation for a beautiful woman, the question is if I really feel that I want to be with her. Something else is when I see this hunk walking down the street with his little tight black shorts and my heart goes full speed. That gut feeling never happened with women." When Bern was asked why he thought he could not love a woman again, he had this to say:

It always felt different. Right after I broke up with her, when I still considered myself bisexual, I had not closed that door. I remember meeting this guy who became my boyfriend for awhile. I remember all the stars in the sky being very bright and the feeling of complete happiness 
and excitement. I remember feeling love for my girlfriend but not the same. I really started to look at the difference between men and women; when a man smiles at me and I look at his body that definitely makes a response in me that was not there with a woman.

Some people indicated that bisexuality had a stigma both in the gay and in the straight community. Those people who had gone through a period when they had had romantic relationships with both men and women, indicated that bisexuality had been part of the process of exploring their sexuality. The purpose was to define themselves either as homosexual or heterosexual. They indicated that a bisexual identity had never been considered as a possibility in defining their sexuality, as Dave, age 41 , expressed:

My perception is that everyone has a certain amount of bisexuality and homosexuality in their potential behavioral make-up. In the gay community ... there is a lot of prejudice against people who claim to be bisexual. I guess that to a certain extent it's kind of messy because you "want it all" and you can't really focus on one thing or the other.

This is interesting to note since a number of people in the sample said that human beings are born with a bisexual potential, but still they did not see this as a choice for themselves. The explanation for this contradiction, as some of the people in the sample explained, was that bisexuality adds a third dimension to the already two dimensional problem of a black and gay identity. Some explained that bisexual people are confused and can never be one hundred percent satisfied because when they are with a man, they want a woman. Yet, when they are with a woman, they want to be with a man. Thus, the only way for a bisexual person to be satisfied would be to have sex with both a male and a female lover at the same time.

Some people make a conscious choice when they chose to identify as gay rather than as bisexual, in order not to be just "hanging in between." Some research indicates that bisexuality is more frequently found in the black community, than in the white population (Staples, Masculinity, 90). This may be 
a reflection of the black community's long tradition of male entertainers and of men in other professions classified by the white population as "feminine." This allows the black male a greater expression of his feminine self in the black community context, than what would be socially acceptable for a white male in a white community context.

Another issue discussed by the sample was that of how a person arrives at the point where he says "I'm gay!" Is a man gay if he has once eroticized about other men? Twice? If he has touched other men sexually? If he once had a sexual experience with another man? Then, are not most people gay? The sexual act is, of course, only one aspect of homosexuality, just as it is only one aspect of heterosexual relationships. The emotional level is, in most cases, just as important in defining one's homosexuality. Bern indicated this when discussing how he had come to define his own homosexuality after having had sexually stimulating relationships with women.

Most societies organize many of their social structures according to gender. Sometimes this is by force rather than by choice, as in prison and in the military. This results in extensive interaction between people of the same gender, often with the total exclusion of the opposite gender. Many people go through a period in their lives when they have sex with the same gender, either as part of ritualized homosexuality, as in some parts of the world (Herd, The Sambia: Ritual and Gender in New Guinea), or as a matter of choice. Lang, age 52 , shared his experiences from the U.S. military in Vietnam:

I've had guys come up to me in the military and say: "I'm not gay but I want to make love with a man." I was openly gay. I was interrogated twice. The second time I was being interrogated, they asked me these stupid questions: "Do you eroticize about another man?" I was beginning to look at this panel of people interrogating me and I go "hmm;" there was this Major sitting there that I had sex with the other day (laughter). He was beginning to feel a little uncomfortable recognizing me. So he said: "Well, I don't think we have any further questions." (laughter). 
In summary, the sample varied in their experiences of defining a gay identity during their childhood and adulthood. The age of the person seemed to be associated with what type of experiences he had had as a young person. AIDS has changed what it is like to be a young gay person today. The older people in the sample explored their sexuality during a time when the sexual revolution caused both homosexual and heterosexual young people to revolt against sexual taboos. Being gay meant being part of this sexual revolution.

Personality played a role as well in how willing and able the young person was to explore his homosexuality from an early age. Some people had gotten scared by homophobic comments, had suppressed their homosexuality for a long time, and went on functioning as heterosexuals. No person in the sample defined himself as bisexual, despite often loving and stimulating relationships with women in the past. This was often explained by the stigma attached to being bisexual, and all the identity problems associated with it.

\section{Coming Out}

I was warned / that if I followed my / unconventional desires slept with a man / satisfied wants / fulfilled needs I would burn in hell / fry forever

So / I tell them / "Start the barbecue"

- Buchanan in Saint, The Road, 20.

It is one thing to come to the point where one identifies oneself as gay. It is another to cope with how one's family, friends, and community will react when or if they find out. The sample had different experiences in this regard. Those who identified as gay early in life, often had not lived in the closet at all. People around them had, to a greater or lesser extent, just accepted them for who they were. Eric, who at the age of 36 was in the process of coming out, claimed that there were no support networks out there in the gay community to help with this process. Once people are out, they do not ever want to have to deal with that experience again. As a result, they stay away from those people who are 
coming out. There are probably more support networks for young people dealing with their homosexuality than there are for older people. Often coming out of the closet becomes harder the older one gets because one's life has become more complex. And, if one is married and has children, one has obligations to other people as well as to oneself. Eric talked extensively about this process during the interviews, since he was in the process of dealing with his homosexuality for the first time.

It seemed that the younger people in the sample had used different support networks in the process of coming out. When he was younger, Bern, age 30 , had been to a number of summer camps, where they talked about homosexuality and where he found strong gay role models. Oscar, age 23 , had talked to a school counselor abcut his homosexual feelings at a time when he was sexually confused. He had been encouraged to live out his homosexual feelings rather than to repress them. Karl, age 31, looked up a gay group as a teenager, but was very discouraged because of the racism he experienced there. None of the older people in the sample expressed having had formal gay support networks while coming out, and the exploring had been done on their own.

Homosexuality in the United States is talked about more today than a few decades ago. Young gay people today have a better formal support network to help them deal with their homosexuality. Many schools, particularly in the San Francisco Bay Area, have counselors who are specialists in helping students who are going through difficult times in regards to their sexuality. A number of gay organizations have been established for support as well. There is an indication that most of these support organizations are formed for and by white gay people. Consequently, they are not always sensitive to, or concerned about, issues important to people of color. Some networks do exist in the black community as well, but there are very few.

Eric, age 36, indicated that black people were more likely than whites to marry and start a family before coming to terms with their homosexuality. Others indicated that most black gay people live in black communities and will, 
therefore, either live in the closet or come out in the black straight community. Gay white people often choose to live in a so-called "gay ghetto" where they can live a gay lifestyle with less concern for family and the straight population. This correlates with what a number of people stated regarding a tighter family structure among blacks, as well as the fact that black families will not "write off" their sons or daughters simply because they are homosexual. This will be discussed in greater detail in the next chapter.

When discussing possible differences between the lives of black and white gay people, it is important to note that this study is based on interviews with only black people. All comparisons made regarding the behavior and reality of black versus white gay people is based on statements made by the black sample, and not on how white gay people have experienced similar situations.

In summary, most people in the sample indicated that they had received support from friends when disclosing their homosexuality. No peison indicated having been rejected by friends, but a few talked about women who had reacted very negatively because they had been romantically interested in the person. Most people described their mother's initial reaction as negative, but they were later supported by them. This is also described in greater detail in the next section.

The experience of coming out is closely connected with the experience of coming to terms with being gay. It depends on the age of the person when coming out, as well as on personality. Not everyone in the sample could point to a particular process in coming out, like Lang, for example, who had always made his homosexuality fit in. 


\section{RELATIONSHIP TO FAMILY}

Family played a central part in the lives of most of the people in the sample. Most of them had come out to their families and had the acceptance and support of their families. Most said that they did not know of any black gay or lesbian person who had been rejected by their family after revealing his or her homosexuality. Most of the people in the sample had a single parent upbringing.

The question asked of the sample was: "Tell me about your family." The family was therefore defined differently among people in the sample. Some included extended family as part of this definition, and most people talked about their grandparents. The two people in the sample who had children and had been, or were, married talked about their wives and children. At least two people had gone through wedding ceremonies with their partners, and a number of people had at one point or another considered adopting children or having children on their own. Most people had close relationships with nieces and nephews, and children played a very important part in their lives.

Eric and Bern made some observations about black and white concepts of family:

The idea of leaving the mother and father and clinging on to the wife, we don't do that, that's very definitely a white concept. Who is it that wrote that "a son is a son until he takes a wife. A daughter is a daughter all of her life"? In black families, because a black man never gives up his mother for nobody, a son is a son all of his life too. So our whole process and sense of family is different.

- Eric, age 36.

You see white gays that leave their communities. I have met people who have completely written off their families. I know people who have had their father beating them up because they are gay, and being thrown out of the house because they are gay. I don't know of any black person, 
actually one comes to mind, but except for that one, who has written off their family. I think the whole concept of family is really very different.

- Bern, age 30.

\section{A. PARENTS}

Most people in the sample considered themselves close to their family, and most people spoke very dearly of their mothers. Some had very colorful and interesting stories to tell about different family situations. Karl told the story of his mother. It had many elements in common with stories told by other people in the sample. Most of the people talked about substance abuse, as well as physical abuse, in their families. This was Karl's story:

I learned when I was 16 years old that I was a product of a rape. My mother came from a very strict home which consisted of a father and a step-mother who was not nice to her. When she was raped, by one of her step-mother's adopted foster children, she was scared and she did not know what to do. She did not know that she was pregnant but she knew that something was happening to her body and her stomach started to grow. She was 17 at the time. When her stomach started to show she was put out of the house. Back then it was always the woman's fault. She went to New York and kind of lived on the streets. She then came here to the Bay Area because her mother was here. She met who is my father-figure here, and I was born at the local military hospital. They were married. I learned all of this when I was 16.

When I was born, my mother worked very, very hard. She was a high school drop out. She was determined to make it, but she had a very insecure, very jealous husband, who feit very inadequate and he beat her up to control her because he felt so irrelevant and insignificant. She was the bread winner. My father did not work consistently, he was a very part-time welder. He was often fired or he quit. So, my mother was the one who worked and took care of us. She was often not emotionally available to me, because when she came home, she was tired. My mother also had an abusive husband. He was very abusive to my mother, and I grew up watching this stuff.

My mother learned to be very angry at men because my father was abusive. .... My mother was going to school while she was working full 
time. I graduated from junior high school the same day my mother graduated from high school. So we shared that, and that is very special to me. My mother graduated from college when I graduated from high school. She then had her BA degree, but she continued going to college to prepare to take the Bar. She is a lawyer today.

Ned was half black and half white. His family had not been close due to disapproval of racial mixing from both sides of the family. James, age 57, had both black, white and Cherokee ancestors, and he came from a very close family. He grew up in a small town where his grandparents had once settled. His mother worked as a domestic for a rich white woman, and James described her as very powerful and strong willed. He was the only black child at school. He had told his mother that he was gay when he moved to California at age 28. Before his mother died of cancer, she told him: "My only regret is that I wasn't there for you when you were a teenager and going through a lot of these things, but I just didn't know how to reach out to you and do anything for you."

Andy, age 36, wrote and told his mother that he was gay after he had moved away from home. His mother wrote back and told him that she did not approve, but that she wanted him to be happy. His parents had divorced when he was in fifth grade. Most people had grown up in a single parent households, and most had lived with their mothers while growing up. Most people spoke of their mothers as strong and dominating. Lang's mother left when he was nine, and he had lived with his father and his grandmother until he was sixteen. Then he had moved to where his mother lived, and they had become close later in life. Ned had never been close to his white mother. She had been very abusive towards him, and he talked about many nights being wakened by his mother's beatings. Garry, age 42, was the second oldest of nine children, and since his mother had raised her children alone and had to work hard seven days a week to support them, Garry had taken over part of the mother role in the family.

The sample varied greatly in their relationships to their fathers. Ned, age 37 , had a very close relationship with his father, as he explained: "My father never had any problems with me being gay. He still does not. He's going to have a 
problem if he doesn't stop bringing guys over for me to date." Conrad, age 51, had become closer to his father later in life. A turning point had come when he told his whole family that he had tested HIV-positive. A number of people had grown up with father-figures, rather than with their biological fathers. Some did not know their biological father. The relationships they had had with their father-figures varied. Some people in the sample were close to these men, while others were not. Karl, age 31, told about his father-figure:

My father died last February. Once I understood his struggle I was able to forgive him and hug him and love him. That's what he needed, that's what was missing. He was a man with an ego, so he would never admit anything, but hardly anybody in his life ever said: "I love you." He came from a dysfunctional family also. He would call me sometimes, to pretend to have something he wanted to talk about, because he knew that I was going to tell him I loved him sooner or later during our conversation.

Not all people in the sample had come out to their parents. Some who came out later in life had either chosen not to tell their parents or their parents were no longer alive. Eric, age 36, explained why he had chosen not to tell his parents:

My mother does not know that I'm gay and I will not tell her ... I have a brother who is gay ... He told my mother, and she said: "You know, you're my son and I'm going to love you and respect you for whatever situation you're in." ... Later my mother told me: "You know what, it really hurts my heart that your brother is gay." I asked her why and she answered, "because I feel that I did something wrong." ... So based on that interaction, I think it would be cruel for me to tell that: "Well, two of your children are gay."

Some people experienced periods in their lives when they were not close to their parents. Often this was associated with the time when they had their first confrontation about being gay. Bern, age 30 , revealed that when he and his partner decided to get married he received very little support from his mother. And, his sister would not come to the wedding. He went through a period when he did not want to speak to his mother because of this. He also recalled many 
times when his mother had been very supportive and letting him cry on her shoulder after breaking up with boyfriends. Conrad, age 51, told a story about coming home on vacation from: college and his mother confronting him with his homosexuality. They had gotten into a big fight. His mother wanted him to talk to the minister: "She told me I had to talk to the minister, and of course I already had had sex with one of the ministers." They did not speak for six months until she finally wrote a letter which started the dialog again. Their relationship then rekindled and got closer and closer over the years. This is probably what Bern referred to when he explained what he considered to be the main difference between black and white families; in the black family "when all the shit is said and done and the fighting is done, you can always go home."

\section{B. OTHER FAMILY MEMBERS}

All the people in the sample had siblings. Most people came from large families, and had up to thirteen brothers and sisters. Most people in the sample had three to four siblings. Most reported being close to some of their sisters or brothers. Some had distant relationships with their siblings, and not all siblings knew about their homosexuality. Some had half-brothers and sisters whom they were not close to. Only one person reported having had a major confrontation with a sibling because of his homosexuality. Ned, who had tested HIV-positive, had this to say about his sister and brother:

My next older sister has one child who is a transvestite, HIV positive, hustler who is doing crack and has done for about eight years. She does not want to deal with the mistakes that he might have made, and she's always asking for advice but never following anyone's advice. My younger brother I have not seen in two years. The last time he visited me, he said he could smell death in my apartment, and he has not been back since. He has had a couple of children since then, but I have never seen them and I probably never will. He said, "My mother died, my brother died, and now you're dying. Everybody is just leaving me and I'm mad about it." I told him that I'm not dead yet and that there are still things to enjoy, but I really don't have time for him and that bullshit. I'm living my life 
cramming as much as possible into the final days of my life and I have to be with people who will accept me and help me and don't put me down.

Eric, age 36, had thirteen brothers and sisters, but three had passed away. He used to be very close to his oldest sister who died of AIDS. He explained the difficult relationship he had with his oldest brother:

My oldest brother and I had a love-hate relationship. He gave my mother more grief than the rest of us did together. That always bothered me. But I took his death pretty hard. He was my big brother, and although I didn't like the things that he did in life and brought home on our mother, that was her burden and not mine, and that's how I saw it. There was nothing I could do to regain the negative energy that he was bringing about. I finished high school when I was 15 to balance out the fact that he did not finish. But somewhere down the line, I stopped trying to compensate for the things that he didn't do. It just wasn't my responsibility.

Most people expressed very warm feelings about their grandparents, especially their grandmothers. Some people seemed to be closer to their grandparents than their parents. Conrad: "I think my grandmother knew from way back that I am gay, but she never confronted me with it. I think mothers, and especiaily grandmothers, know."

For Eric and Frederic the concept of family was broader, since it included marriage and children. Frederic had a good relationship with his youngest daughter only:

It's been very tragic with them and me. I guess I just don't talk about it very much. I have a relationship with my youngest daughter. My ex-wife and I were very bitter in the marriage and the children were born in a war-zone ... My older daughter comes here at times, and she really is very troubled. And my son, I have not seen him since 1988 or 1989.

Lang, age 52, had a different story to tell, a very tragic story. He and his partner took care of his sister's children together. It was very difficult for Lang to talk 
about this period in his life. This is a story which illustrates the extended family concept more common in black than white families:

Let me show a picture of me when I was young. This is my other brother who lives here. He is gay too, and he has AIDS. Right now he is in the hospital and he is very sick. I never thought anyone knew, but everybody always knew he was gay, but not me. He is two years older than me. I also have three sisters. These are her kids. I raised them. My partner and I raised them. My lover and I. He died of AIDS in 1984. He was so sick that he committed suicide and I helped him. But my sister and I became close when I moved out here. She's a singer and we had all these plans that I was going to be her agent and everything. She became neurotic. She started having babies by different men, and then she could not handle the kids anymore. My partner and I had been together for three years when she dumped the kids off at our door. We went to court and we got the custody of her kids. She's now somewhere in Europe.

We got a social worker and we got welfare, how else were we supposed to raise 4 kids? You only see 3 kids in this picture and that's what I'm getting to. They came to the house to remove the kids because we were gay, said they had to protect the kids against AIDS. That was a very ugly day. The kids reacted, they spit at the police and they hid around the property. It was just a really, really bad scene. Life changed after that. I began to get into drugs. We just did not know how to handle it. It was bad enough the things we had done up until then. Things never got back to normal. The kids started using drugs and I started using cocaine a lot. The mortgage money went to drugs. In the meantime, I was beginning to fall behind in my job, and things were bad.

Three months later we woke up and there was smoke in the house. We could not get into the room of one of the kids and, as a result, he died in the fire. My partner never got over it. That's why he committed suicide, because of the guilt. My partner was a white man. We were the model family. We lost the house, we got evicted. My plans to get a Masters in Nursing went down the tubes. I left, I could not handle it, leaving the kids with people in the area. When that kid died ... He was just so incredibly beautiful. His father was French. Everybody in the area knew this kid, he was so popular. In his funeral, the whole town closed down and came. It was an incredible town. At his school everybody knew that we were gay, all the kids accepted it. In fact, my partner and I went to the class and talked about what it's like to be gay. 
Most people in the sample, at one point or another, frequently in the context of a long term relationship, had discussed with their partner the possibility of adopting a child. Bern, age 30, was, at the time of the interviews, single, but wanted strongly to have a child on his own. He did not want to adopt, but to find a woman to have a child with. Most people said that they loved children and that they had very good relationships with their nieces and nephews. This is what Eric, age 36, had to say about his children with respect to his homosexuality:

Right now my position is that my sexual orientation has no direct effect on my relationship to my children, I'm their father, period. Whether I'm gay or straight or bisexual, I am their father. It's not a desire or necessary for me to present their young minds with the idea that their father is gay. I think if I gave them that information right now, it would change the course of their lives, because it would effect them so dramatically.

Conrad had been thinking about adopting, but since he was diagnosed with AIDS he decided against it: "My partner and I had talked about adopting kids in the early stage of our relationship. There is always a need for adoptive parents. If it had not been for this particular situation with AIDS, I think I would have. I did not feel that it would be practical, not knowing what my status in the future might be." Dave, age 41, had thought about adopting, and this was his view:

I guess if I were to be a real chauvinist, in comparison with the "breeders" of the world, (laughter), the role of a gay person is to nurture the kids who are already in this world without much guidance, and to turn them into real human beings. A lot of gay people I know nurture their nieces and nephews. My experiences in my family has always been to bring people into the family and help them because that's what you're supposed to do. So, adopting people you see have some potential and helping them out, is the thing to do. I'll be satisfied if I don't have children of my own, but can make a difference in someone else's life.

Karl, age 31: "Children are a very big part of my life. I have nieces and nephews I love and adore and who love and adore me. I'm very conscientious 
about children because I think a lot of children are badly conditioned, and set up to be crazy folks in terms of how the society conditions us."

\section{SUMMARY OF FINDINGS}

Most people in the sample were close to their mothers. The importance of other family members varied, but most people expressed that family played a very important part in their lives. Some pointed to what they saw as a stronger family structure among black than white people. Most people mentioned substance abuse in their families, and some told stories of their mothers going through hardships in terms of abusive husbands and having to work hard to earn money for the family while they where growing up. Some people grew up with fatherfigures rather than their biological fathers. Most people had experienced periods when they were not as close to their families. This was often during the time of coming out.

\section{ANALYSIS}

Family played a very central part in the lives of most people in the sample. Most of them were out to their families and had the acceptance and support of their families. Black families appeared to be more accepting of "non-traditional" gender roles than white families. Most of the people expressed that they did not know of any black gay person who had been rejected by their family after revealing his or her homosexuality, but they all seemed to know of a number of cases where that had happened with white gay people. This may be one explanation of why gay white men create gay ghettos such as the Castro district in San Francisco, while black gay men tend to stay in their black communities. 


\section{Parents}

In retrospect, it wasn't the sound of my mother crying that hurt most. it was the sound of my father leaving his marriage, his house, his familiars.

In the debris of ruptured bloodlines, in the domestic violence of our families, in the turbulence we call love was bred the possibility of my dysfunction, and yours.

- Hemphill, Ceremonies, 34.

What really stood out in the stories of the people in the sample was the solid family structure, often with a strong mother in the center. This was best illustrated by Karl's story. Most people expressed things similar to that of Garry, age 42: "Women are the movers and shakers in the black community and in the black church." Some of the stories, like that of Karl, described strong women who had managed to keep the family together. Some had grown up with father-figures rather than their biological fathers, and most people expressed being close to their grandparents.

Most people spoke of dysfunctions in their families, both in the form of substance abuse and physical abuse, as both Karl's and Lang's stories indicated. A number of people referred to family members who had been killed, often in drug-related situations. The most notable thing about these stories is still that all this pain seemed to have pulled the families together and created a tight structure of support. This was also evident in the stories told by the four people in the sample who had tested HIV-positive. When they told their families, they had all received support from family members.

Most of the people in the sample had divorced parents, and most of them grew up with their mothers. A number of people indicated that they had had to take on a parent's role, because of substance abuse by a father, and a mother who 
had to work hard outside the home to support the family. It is still important to emphasize here that not all people in the sample came from dysfunctional families, and that dysfunction in the family is not necessarily connected to growing up with only one parent. However, at least seven of the thirteen people in the sample talked about severe dysfunctions in their families.

People in the sample had different experiences with their parents when they first disclosed their homosexuality. It varied from big fights and not talking to parents for a period of time, to a complete acceptance of the fact. For a number of parents, the news about their son's homosexuality was no big surprise. Most parents, and as Conrad claimed, especially grandparents, were able to sense early on if their child was gay. Some parents reacted strongly because they had refused to admit that their child was homosexual. Only two people in the sample had not disclosed the fact that they were gay to their parents: Frederic, age 60 , because his parents had passed away before he defined himself as gay; and, Eric, age 36, because his mother had been very distressed when Eric's brother told her that he was gay. The rest of the sample had told one or both parents. Two people had had major confrontations with their parents over the news, while the rest had received differing levels of acceptance. No particular pattern was found in the parents' reaction to learning of their son's homosexuality.

Based on this research, as well as other theories and research, it appears that the black family is more likely to accept a homosexual child than the white family. An interesting question then results: Could this have something to do with the overwhelming number of black female headed households? Many people indicated that mothers, rather than fathers, were the first ones to embrace a homosexual child. This may, of course, be the case because most of the people in the sample had been raised by only their mothers, and the contact they had with their fathers varied. 


\section{Other Family Members}

Two people in the sample had three children each. One of them was married to a black woman, while the other had divorced his black wife. One person in the sample had recently gone through a wedding ceremony with his gay partner, and another person had gone through a ceremony a few years earlier, but had, at the time of the interview, split with his partner. No questions on partnerships were asked, so there is a possibility that more people in the sample had gone through this ceremony without expressing it during the interviews. Partners were, in this respect, included in some people's definitions of family.

It is interesting that about half the sample expressed being very close to their grandparents. Some had lived near to their grandparents while growing up, and some told warm stories about their grandparents, especially their grandmothers. Depending on the age of the person, some told stories about their parents, but in most cases their grandparents, working as domestics for white people. A number of people who considered themselves activists for black's rights today seemed to have received a great deal of their cultural identity through their grandparents. A number of the people in the sample had grandparents who had been born in the 1800s. They engraved strong values in their grandchildren, often in terms of the value of family, and giving back to one's community. A number of people talked about very dignified grandparents who had taught them to be proud of their heritage.

Dave, age 41, had learned much about how his ancestors had built a strong family structure from his grandparents. He was at the time of the interview working on a project to illustrate the strength of the black family and in the black community in the early 1900 s and up through the 1950s. Karl was the only one in the sample who spoke of having travelled extensively in Africa, and his African heritage was very important to him. 


\section{The Concept of Family}

Most of the people talked about the strong black family structure, and some gave examples of the fact that a black family does not reject other family members. In particular parents would not reject a child. Despite this, some stories surfaced indicating that this rejection exists in one form or the other. In Karl's story about his mother, he stated that she was thrown out of the house when her father and step-mother found out that she was pregnant. In Lang's tragic story about his sister's children we find another example of children not being wanted--a mother leaving her children to be adopted by her brother. Both sides of Ned's family rejected the children who had resulted from an interracial marriage.

Do these stories indicate that the tightness of the black family structure only is a myth? Or, do white families on average have more rejection than black families? Despite the fact that one can pull examples out of these stories indicating that not all black families have a tight structure, what remains is the enormous strength and courage of both Karl's mother and of Lang and his partner.

Any type of change which greatly influences the lives of a group of people will aiso force about a change in the structure and norms of the group. In anthropology one has many examples of this change taking place when a small isolated society is introduced to the ways of the West. The structure of the black community and the black family went through changes first after the Civil War and later during the civil-rights movement (Staples, Family, 21). Conrad described what he saw as an identity crisis in the African-American family as being a consequence of the civil-rights movement. He said that the civil-rights movement contributed to breaking up the black community, but he strongly emphasized that he is all for civil-rights:

When I grew up I went to totally segregated schools, and all my teachers were black. I know I had role models there because I didn't look outside the community to the white folks, I looked at doctors and lawyers, and 
they were in our communities. That was very important. That was the way it was for a long time for African-Americans. But then you are right, once the civil rights, to a degree, opened up for some integration and people felt that that was the way to go, 1 think it did break up the black communities. In some ways it opened up the system to blacks who could rise up to the top, and they split. A lot of them made it, so to speak, education, money, and then "we're out of here," leaving those who did not make it, for whatever reason, to form underclasses, a low economic group.

One can talk about a backlash in the African-American community and family after the big changes brought about by the Civil War and the civil-rights movement. Many of these changes had an economic foundation, like Dave, age 41 , explained:

When people could go to the predominantly white downtowns to shop they no longer felt compelled to shop in their neighborhoods. The things sold in their own neighborhoods were automatically considered inferior just because they were not sold in the predominantly white stores. So, just during sort of the height of development and being, in essence, everything that downtown was, except for not located downtown, the community dealt with this devastating blow. People were just deserting it in hoards and going down and supporting the nice restaurants downtown as opposed to the ones in their neighborhood. This meant that the economy in the neighborhood went down, and the neighborhood itself was no longer attractive. Now we see in urban areas, with large concentrations of African-Americans, the shell of what once were beautiful, thriving neighborhoods.

This is not to imply that, without the civil-rights movement, a change would not have taken place in the black community and the black family. The rightness of the civil-rights movement is not the question. One must keep in mind that even the civil-rights movement had a white context--it was operating within the white power system. Some power was given up, at least on the surface, but not much. The United States has still not seen a person of color as president, and many claim that the only black candidates to reach high political offices are white people with black faces. There is also a tradition of assassination of black leaders who gain support, like Martin Luther King and Malcolm-X. As Staples 
writes: "The survival of the black family and sense of community in American civilization is a measure, in a sense, of his success in adopting the culture of the whites, or an indication of the fact that blacks have found within the white man's culture a satisfying life and faith in his future." (Family, 27).

The black family and community structure have gone through rapid changes during the past number of years in the United States. As possibilities opened up for integration into the white communities, many black people looked for new opportunities outside the black community. This process had consequences for the black community and to a degree weakened what had been a very strong community. However, the concept of family seemed to have survived these changes. As the stories of the people in the sample indicate, most people do have the support and love of their families. 


\section{TRANSGENDER ISSUES}

The most important issue for me is just survival. I have practically met all my goals: I've had my surgery done, and I wanted to have a nice job and dress up. I never saw a husband in the future, but I wanted to live this life as a single, attractive young lady. I've met all those goals so far, and now my struggle with myself is really survival, and to try to keep my head above water.

- Mira, age 34.

Mira was included in this sample because most of the social aspects of being a transgender person was missing from the literature. How does the general population react when a transgender person walks down the street? What does a transgender person want in a partner? How does a transgender person come to terms with her, or his, own sexuality? What kind of family support do transgender people have? These were some of the questions asked of Mira during the interviews. Mira was asked if she knew how many transgender people there are in the Bay Area, and she had the following answer: "I don't know. I would really like to find out, but I don't even have an idea of where to start guessing. Nobody wants to do an in-depth study of transgender people or even include them in surveys or any of that stuff, so we're excluded all the way around."

Mira was interviewed twice. She was the only transgender person in the sample. The word transgender will, for the purpose of this chapter, be used to describe a biological male who lives as a woman, either with or without having had the sex-reassignment surgery. This chapter is about Mira and the issues she sees as important to her and other transgender people. She worked as a counselor for transgender people, so the issues that she addressed were drawn from the experiences of many transgender people. The format of the interview and the specific questions asked were similar to those of the gay sample, but the terminology was adjusted in order to address Mira as a transgender person 
who identified as a woman, rather than as a gay man. Also, different questions were asked as they came up during the interview, depending on the issues Mira herself addressed.

\section{A. PREJUDICE}

Mira experienced a lot of prejudice. It came from within the gay community in particular, but also from the black community and the general population. She had gotten used to being the subject of laughter and comments when she walked down the street: "It's very scary when you see somebody who is not what they are suppose to be. Especially for little kids, but for adults too, especially teenagers and men. It must be threatening to them or whatever. i don't know the psychological effect it has on them, but it has an effect anyway."

During the interviews Mira often expressed the negative experiences she and other transgender people had in the gay community. She claimed that transgender people are subjected to more prejudice from gay people than from anyone else. She speculated that it had to do with jealousy, since some gay men want to be transgender, but they do not dare. She compared gays' treatment of transgender people in a gay bar to the experience of black people when they walk into an all white bar. Mira said she usually had no problems in straight bars, even if the men there could tell that she was a transgender person. Even lesbian women are not comfortable with transgender people:

Even lesbians. They have a woman's festival in the summer. It is for women only, and they have made very clear that no post-op women are allowed. That would include women like myself before surgery. It's like "what are they going to do?" Have someone stand at the door to check you? I said, "what an insult." They say that only naturally born women can come to this. Both of these things are things that make me angry when it comes to gay and lesbians and the way that they feel that we are not real people to them. 
Another issue Mira expressed concern about was the fact that drag queens make a living out of making fun of people who cross dress or identify as transgender. Mira felt that these people had a certain obligation to make it known to their large audience that this is not entertaining for transgender people:

The only images you have of transgender people are in entertainment. Everybody loves these images because they can turn them off and then go home living as guys. .... That's why l'm skeptical of these entertainers. They take the images of a cross dresser to the extreme. Everybody knows that nobody would walk around with a big blond wig and seven inch platform shoes. Nobody would do that nowadays. And that goes back to that this is entertainment. And that's how people look at it. I don't look at it as entertainment because it's not.

Mira worked as a counseior for transgender people at a resource center in the Bay Area. As a result of her work, she had been invited to speak about transgender issues to gay organizations. She expressed that this was most often an unpleasant experience because the gay people would laugh at her and not take her seriously.

In summary, Mira had experienced prejudice from the gay, as well as the straight, population. Still, she claimed that the gay population was worse than the heterosexual population in terms of discriminating against transgender people. She speculated that this could have something to do with the fact that some of the gay men wanted to be women themselves.

\section{B. PARTNERS}

Most transgender people are heterosexual. For Mira, who had been born a male, but had gone through surgery, that meant that she dated men. Mira explained some of the issues related to being transgender and finding a partner: "I know some girls who just have to have a man. They need a man to 
make them feei like a woman. They will go through almost anything, any extreme, just to say, 'I've got a husband, I've got a man.' That is so unhealthy. I don't think I will ever be in that position." Mira explained that many transgender people were so eager to find a man that they would end up in very abusive relationships. She said this could be related to the lack of approval by family, friends, and society in general. The man was then able to take full control of the relationship and would condition the transgender person to accept anything from him. Most transgender people would because of the lack of support from others.

To the question "Have you had any relationships?" Mira responded:

Short relationships, yes. Looking at relationships in the past, looking at my parent's relationship, looking at girlfriend's relationships, there was just something about that that I felt that I didn't want to get involved in. I don't know if it's going to turn around. There have been people that 1 have really cared for, and men that have really cared for me, but it seems like after a certain point it gets like: "You again!"

Regarding her own relationships, Mira said that because she had always had great support from home, she had never let herself be abused in a relationship:

In a man ... I want somebody who is down to earth, intelligent, understanding, compassionate, and who has a sense of humor. All of those things. Preferably the man in my future will be a black man, or even Italian. I have had some nice relationships with Italian men. I would not really exclude any race. I have come so far now that it does not bother me to be by myself. I'm able to have a pretty active sex life. It used to be more active but after the death of my parents. I just have not been into it. But before then, I always had a very active sex life. I might even have gone to the point of being promiscuous.

Mira claimed that many transgender people get into unhealthy relationships because they want a man so much that they will accept any one who wants them. Mira said that this need for a man was often related to the lack of support 
transgender people usually receive from their families and from society in general. She pointed out that her personal experience had been different because she had always had support from her parents.

\section{TRANSGENDER IDENTITY}

Mira identified as a woman. She also identified as transgender, but for the purpose of her everyday life, she was a black woman. She also claimed that transgender people could be considered a third gender:

I don't identify as a transsexual. I might sometimes say a transgender woman, but I basically identify as a black woman. Like I tell my clients, and what I firmly believe, is that unless it's necessary that it comes up there are not many situations that require that somebody knows my life history and what I was before and so on and so forth ... I do consider transgender people to be an additional gender.

According to Mira, most transgender people grow up without any transgender role models. Often they are on their own to discover what is going on physically and emotionally, and they often end up on the streets as prostitutes. Prostitution might be the only alternative that they have to live as transgender people in an environment that will accept them. Often older transgender people on the streets will take the younger ones under their wings. Mira had an older sister who was also transgender, but she had not received much support from her sister while she was in the process of defining her own transgender identity. Mira discussed her own reaction when she first met transgender people, and her experiences when she first started cross dressing:

I first met another cross dresser when I was about 9 or 10 . My sister, since being the first person, I had seen her dressed up in the house, but besides her. I came over with my school on a field trip and my sister happened to live around the corner in a hotel. I had told her I was coming over so she met me and took me to this hotel. There were all these ... oh man, I was scared to death. I couldn't get across the image that these 
people are men dressed as women. They were wearing blue eye shadow all the way out to here... That was the first experience of seeing them. People who are out working on the streets are all hanging out together. It looked like they were having a good time, but to me they were just scary looking, because they were so big and ... it was strange.

I ran away from home when I first started cross dressing. I was like 11 or 12. After then I was working on the streets in prostitution, which is what I survived on. I was learning what it takes to survive if you're going to live this life from other transgender people who were older than me. They would take me under their wings. At this point my sister, who was older than me, had kind of expressed that she wanted me to do things her way or I had to go back home. I did not want to go home at the time, so the other girls stepped in as kind of surrogate mothers and sisters. They taught me a lot about the streets and what to do in order to survive.

Many transgender people go through sex-reassignment surgery. Mira had her surgery done some time before the interviews took place. She used the terms pre-op and post-op to describe people in terms of having had the operation or not. Mira claimed that she would have liked to have been born a woman, but that she did not feel trapped in a man's body. Rather, she was "born a woman with a birth defect." She was in the hospital for two weeks after the surgery, and it was extremely painful. She explained the feelings a transgender person often has after this major surgery:

There is that point after the surgery when you are depressed and you ask yourself why you did it and if it's going to work out. It's a major surgery first of all. If you come out of it and there is nobody there to support you, you've got to be really strong. You have all these feelings going on. Your body has changed and you ask yourself what you are going to do from there: "What was the purpose of doing this?" "What am I going to do with this?" All these questions come up.

According to Mira, transgender people often end up on the streets as prostitutes as a consequence of having no support from either family or other people. Mira had gone through sex-reassignment surgery, and therefore used the term postop to describe herself. 


\section{FAMILY}

Mira shared the general view of the gay sample that black families accept a greater variety of behavior in their children than do white families. What Mira had to say about black versus white families followed the same pattern that the gay sample had expressed. Black transgender people were seldom totally written off by their families, even though most families did not approve of their transgender life style:

I think there is a tighter family structure in black families. I think maybe just because black people are black--this is just something that I have seen, especially for black transgender people--that no matter how hard it is on the family, they usually don't want to get rid of you as if you never existed. I don't think it's impossible to find cases like that, but it's not common. But with white people, they really feel that they have a lot to lose. A lot of black people come from families that are not that wealthy so they don't have that much to lose. But in the case of white people they worry about their neighbors, their reputation, and this and that and they feel that they have more to lose. You wonder what their child's life is worth to them in comparison with this whole facade they have to keep up. So, economically speaking, I think black people have a tendency to stay more together. Some of the white transgender people I speak with tell me that their parents have said that they don't want to see them or speak with them ever again. The black transgender girls I know will say that they just can't go home and dress that way because it upsets their family.

Mira was not close to her transgender sister; they did not get along. The family did no longer want to accept Mira's sister because she had chosen to go and see her boyfriend, rather than attend the funeral of her parents. But Mira had had a close relationship with her parents:

I just recently lost both my parents, whom I was really close with, so I'm having a lot of difficulty working around that. They were always supportive of me, not at first, but over the years ... There were certain things that we always had disagreements about, "why do you have to wear your skirt so 
short?" "Why do you have to wear a dress cut out like that?" On the issue of surgery and getting my implants done: "Why are you getting them so big?" Those kinds of things

I have enough self confidence now to know that I can make it on my own. But l'm really going to miss my parents, since I no longer can just go home to talk to them, and that's both of them. Of course I always had a sympathetic ear to my mother, but over the years my relationship with my father was just getting stronger and stronger. He was very concerned about the things that could happen to me because of my lifestyle. Sometimes he would just get so angry when I was beat up, or raped, or not able to find a place to stay because they figured out what I was. Just regular things that transgender people go through because of what they are. My father came from the South and he did not like white people at all. He would take that part of his life, the things that were done to him by white people when he was a kid, and, with me being transgender, he would be so angry at the things that happened to me that, at one point, I just stopped telling him.

Mira's mother had basically always been supportive of her being a transgender person, but as she explained, her father had problems understanding her:

My father was supportive only up to a certain degree. His argument was that "ihey have gay lawyers and gay doctors, but why do you have to wear a dress? Why can't you just be a man and wear pants and nobody would ever know what you were and you would save yourself a lot of trouble." I was constantly telling him that that was not what I wanted to do and that that was not what I was going to do, because there's a big difference--a lot of people don't realize it--between being gay and transgender.

Mira had two sisters, two brothers, and one transgender sister (biological male). She explained that she had never been close to her oldest brother because they were very different. However, from the time of their parent's funeral, they had become closer:

My big thing with my oldest brother was that odd time when our parents died--preparing the funeral and all of that. How are things going to work out with him? Since he's the oldest, will he take charge? I couldn't see 
where his conservative attitude would fit in. My thing was if he would insist on referring to me as a son, since I was born a male, but it never even came up. When he showed me the outline of the obituary it read like it was suppose to: three daughters and two sons. My other transgender sister was not included because I phoned to notify her, our parents died three days apart, and she had gotten tickets to go and see her boyfriend and that was more important to her.

Mira explained that most of the transgender people she counseled did not have much support from their families, but that they could go home if they just did not dress up as women. Others only had phone contact with their parents because they refused to go home without dressing up. As Mira expressed it: "What is the use of taking hormones and getting all pretty if you can not go home unless you dress as a guy?" Mira said that when she first started dressing as a woman she would come home all dressed up. But, over the years, she calmed that down. As she said: "I realized that just because you have the right to come here you do not really have the right to disrespect your family. You do not need to be dressing as if you were working on the street, because the fact that they even let you come here is a blessing."

Mira loved children and had for periods of time taken care of her sister's children. She had wanted to adopt children herself, but had decided not to. She explained how her nephew dealt with her being a transgender person: "My oldest nephew, who is 18 now, because he was the first born he really did have a rough time with the kids teasing him about me. I don't know how he dealt with it but by the time he was out of 8th grade he would dare anybody to ask about his aunt, who she was before and whatever."

Mira was working hard for transgender people to be accepted. She informed people about the reality of transgender people through her work with other transgender people and by speaking to the gay community about transgender issues. She said that transgender is still considered a mental disorder, and that it was still in the books as such. She also considered the job she did, informing people that being a transgender person is not entertaining, as important: "That's why my work here is so important ... letting people know that it's not all 
entertainment, and letting people who entertain know that that is entertainment, but do not forget that there are people for whom this is not entertainment, because you are the one that has masses of people listening to you."

According to Mira, many transgender people did not have the support of their families. Some had the option of going home if they did not dress up. Mira had a very close relationship with her parents who had recently passed away. The contact with her siblings had gotten better after her parents passed away. She was close to nieces and nephews, and claimed that children were very important in her life.

\section{E. SUMMARY OF FINDINGS}

Mira and other transgender people experienced prejudice from both the gay and straight population. Mira said that she felt more comfortable walking into a straight bar than a gay bar, because the straight men more easily accepted transgender people. Many transgender people end up as prostitutes because of a lacking support network. Often transgender people have been written off by their families, or they are only allowed to go home if they dress as women.

\section{F. ANALYSIS}

A man who has changed sex is interesting by definition. Few people today react to a woman dressing up in men's clothing, but it is still socially unacceptable for men to dress up as women. Most of the current literature on cross dressing and transgender people concentrates on the clinical aspects of changing sex and on defining terminology for different transgender identities. Still, the emphasis here will be on Mira and what she saw as transgender issues, with less emphasis on transgenderism as a concept.

It is interesting that Mira and other transgender people do not consider themselves to be part of the gay community, since transgender people often 
represent the most visible of what many consider gay images in a community. A number of the gay men in the sample referred to their first experience with other gay people as being with men who dressed up as women in their communities. As Mira explained, there were different motivations behind why men dress up as women, and for many people it was not entertainment. Mira gave this explanation for why transgender people usually were not homosexual and why they did not consider themselves part of the gay community:

The difference that I see is that gay men want to be with gay men. They want to be with other men in a man's water. They want to be with each other relating to each other as men. Transgender wants to be, most of us, with a man in a woman's capacity. I can not perceive what a man would think like because my mind has been geared towards thinking like a woman, since kindergarten and on through school. I guess when I say that I' $m$ going by what the society says, a man is suppose to be strong, a woman is suppose to be submissive and she's suppose to be needy and all those stereotypes.

\section{Prejudice}

Many times during the interviews, Mira discussed the negative experiences that she and other transgender people had in the gay community. She claimed that transgender people get more prejudice from gay people than from anyone else. She speculated that it might have to do with jealousy since some gay men want to be transgender, but that they do not have the courage. She compared gay's treatment of transgender people in a gay bar to the experience that black people have when they walk into an all white bar. Mira said that she usually had no problems in straight bars, even if the men there could tell that she was a transgender person.

People often react to what they see as different. According to Mira, the interesting question then becomes why gay people react more negatively to transgender people than straight people do. The way in which, and to what degree, a gay man expresses his feminine side varies a great deal. Some gay 
men project a very feminine image to others, some project a macho image, and most gay men are probably in between. Often the more feminine a man's mannerisms are, the more other people will connect him with being gay. Some gay men, including some in the sample, said that they did not want to "read gay." These people were often the ones to express negative feelings towards men projecting female images. This supports the explanation that some gay men who do not consider themselves feminine, and do not necessarily want to be perceived as gay, oppose feminine images in other gay men. This is often the case because feminine gay images are often the most visible--sometimes the only--gay images the straight population sees. These gay men may be prejudice against transgender people because they do not want to be associated with men who dress up as women. The image of a transgender person is less threatening for a straight man since his identity is not attached to the identity of the transgender person to the same extent that the gay person's identity is.

It is interesting that Mira felt prejudice from lesbian women as well as gay men. It appears that gay men consider transgender people to be women, while lesbian women consider transgender people to be men. There is no question that some of the issues for lesbian women and for transgender people are different. Yet, it is surprising to learn that some lesbians chose such a rigid definition of womanhood since lesbian women themselves often are subject to discrimination because of this same rigid assignment of gender roles. Perhaps they are concerned about men dressing up as women simply to participate in their special events.

A group which is formed because of hostilities from the outside needs to create an environment in which its members feel comfortable. Still, one might assume that it would be important for this group not to leave people out based on the same issues on which the group was formed. Rather than leaving transgender people out of this support system, perhaps the lesbian community needs to educate it's members on transgender issues. 
On the other hand, Mira and other transgender people do not consider themselves to be homosexuals, and lesbian groups are not for heterosexual women, so there's a problem of definition on both parts here.

Mira was also concerned with the frequent use of transgender images in entertainment. It often projects an image that men dress up as women only for fun. Mira missed an educating element of the entertainment industry. The entertainers have the power to educate people on transgender issues because they have a large audience, and yet, this is not done. It is difficult to educate people about transgender issues when all they do is laugh when they see a transgender person. People in the dragshow industry could entertain and still bring an educational message to the audience.

\section{Partners}

Mira dated men. She stressed the fact that she is not a complicated person and that she wants the same in a relationship as most other people do. She said people had a tendency to make her more complicated than she was. She explained that she looked at men as a woman would. She claimed that many transgender people are desperate to be in a relationship because they need a man in order to feel like a woman. As a result of this desperate urge for a man, they often end up in an abusive relationship with a very controlling man. Mira claimed that because she had had good support from her parents all her life, the need for a man had not been as great as what she had observed in other transgender people who had no support. When describing the man she wanted to be with in the future, Mira described characteristics that many straight women would want in a man. 


\section{Transgender Identity}

As some people in the gay sample noted, transgender people lack role models to identify with. Often young transgender people only have prostitutes on the street to look to for support. This makes prostitution the only visible alternative for them from a young age. Transgender people face many problems as a result of the stigma attached to dressing as a woman, including: problems finding a job outside of prostitution; problems finding a place to live because the landlord might be skeptical due to their appearance, and may require proof of employment; and dealing with constant harassment from other people when walking down the street dressed as a woman. In addition to facing the discrimination of the society at large, they also have to deal with the lack of acceptance, or a total write-off, from their family.

Mira was asked if she had ever felt that she was trapped in a man's body, but she preferred to define it as if she was "born a woman with a birth defect." She pointed out a number of times that she defined herself as a black woman first. Unless it was necessary to identify herself as a transgender person, as was sometimes the case while she was pre-op and working on the streets as a prostitute, she did not feel that it was necessary.

It appears at times that a transgender person, in defining her identity, takes the definition of femininity to an extreme. Women today can dress in anything from a man's suit to a wedding dress. Mira was not asked any particular question regarding this issue. Yet, it is interesting to ask if, in fact, most transgender people dress and act in a way that many would define as taking the image of women, and what is suppose to be feminine, to an extreme? To be more specific, do most transgender people dress in shoes with high heels, wear sexy dresses or skirts with nylons, put on a lot of makeup, and like to fix their hair? Or, is it just that those who do are more visible in the streets? If we do not find the same variations in the degrees of expressing what is considered feminine among transgender women and biological women, and if we in fact would find a greater tendency among transgender women to express what they perceive to be feminine, an interesting question becomes why? 
Mira felt that she was born with birth defects, rather than being trapped in a man's body. There is a possibility that, in the process of defining a transgender identity, it becomes important to establish a strong feminine image in order for oneself and others not to question the feminine identity of the person, despite masculine parts of the body. This, again, can also be related to a lack of role models. Had the society at large been more tolerant of transgender people, it might have allowed for a broader ideal of what is feminine. As a result, transgender people would have more options to express what she felt was her own identity, rather than what is an acceptable feminine image.

Mira described the process which she herself and others have gone through in order to define a transgender identity. Most transgender people have known that something was not right from very early childhood, and are often mistaken for being gay. Transgender people have few role models to look to for support, and they often end up in prostitution because that is the only place they will be accepted. The transgender person's definition of what it means to be a woman may be defined according to stereotypical images of femininity and actually vary less than what is the reality among biological females in the United States.

\section{Family}

According to Mira, it could appear that most transgender people do not have the support of their families. Mira pointed out, as did the gay sample, that black families are more likely to accept a transgender or homosexual child, than white families are. Some transgender people have found a middle ground with their parents, so that they are able to go home if they do not dress up too much.

Mira pointed out that some of her parent's friends had discontinued their relationships with her parents after they learned that they had two transgender children. Mira was very upset at this and questioned what their identities had to do with their parents' relationships. 
Mira had been very close to her parents, who had passed away shortly before the interviews took place, but had not been that close to her siblings. She said that her one brother had impressed and surprised her by arranging their parents' funeral, and acknowledging her as a female, rather than a male, in the obituaries. It is interesting to note that Mira had a transgender sister (who was also born a biological male).

Mira's statements indicate that gay people have more support from family and community than transgender people do. As Mira pointed out, being a transgender person today is the same as being gay twenty years ago. Still, community support and family support are not one and the same thing. Even when a behavior is not socially acceptable, most black parents will find a place for their children in their hearts, even if they do not fully accept or understand their child's lifestyle. How family members accept and treat another family member has to do with the strengths and weaknesses of individual members of that family, as well as on the bond of that particular family. This is shown both in the gay sample and in Mira's experiences. 


\section{AIDS}

The people in the sample were not asked if they had tested HIV-positive or if they had AIDS. Four people in the sample stated that they had tested positive or that they had AIDS. Most people in the sample brought up the topic of AIDS during the interviews, and explained the impact that it had on them and on the black and gay communities. Most people had had lovers or loved ones who had died of AIDS.

Ned, age 37, tested HIV positive nine years ago: "I was diagnosed when I was 28 and now I have absolutely no idea what a healthy adult person feels like. ... Now I can look back and wish I could turn back the clock to the most promiscuous time in my life and be more promiscuous than I was, with the same result." Ned explained that he had a large family, but that he was close to only a few members. He explained the uncomfortable situation that resulted when running into family members: "If they see me they are embarrassed because I'm in a wheelchair. When they ask me "how are you?" I know that back in their minds they're saying, 'this man has AIDS--how is he really doing?' All I can say is, 'I'm still alive.' That's really all I can say."

Conrad, age 51, was not working because he had been diagnosed with AIDS. He explained his health: "I try to get most of my stuff done in the morning, that's why I asked you to come in the morning. After this, I will probably just collapse and rest because my energy level changes. Sometimes I wake up in the morning and I have no energy, it just depends. I ate blueberry pancakes this morning, so I feel good."

Garry, age 42, had also tested HIV-positive. He did AIDS-related work. He talked about the fact that many black gay men who have tested HIV-positive feel that they have nowhere to go, and that neither the black nor gay communities want them when they get sick. He also stated that something is wrong with a 
society which first is horrified by the fact that Magic Johnson might be gay since he tested HIV-positive. Yet, embraces him when it is revealed that he contracted the HIV-virus because of infidelity. In the United States, it is better to be unfaithful than to be gay.

James, age 57, did not indicate that he was HIV-positive, but he said that his three best friends had died of AIDS. He talked about a very difficult time in his life when his mother was dying of cancer at the same time that his best friend was dying of AIDS. He had rushed home to be with his mother, who died on a Thursday, and his best friend died the following day. James cried as he told that story. He said this experience had made him start doing AIDS-related work.

Lang, age 52, had tested HIV-positive some years earlier:

It's interesting that you are doing this, because it's sort of a very intense month for me because it was ten years ago May 18, which is today's date, or May 19, that I was told that I had 6 months left to live. At that time I was in the hospital, and I had all the symptoms of AIDS-related complex. The reason why I remember it, is because two days later I checked out of the hospital. Being a nurse, I took myself off all the IVs and I went back to Northern California where I was living. I spent that whole weekend just snorting cocaine and being stoned. I had decided I was going to go the way I wanted to (iaughter)--no pain.

The topic of how and if people have changed their sexual behavior because of AIDS came up frequently during the interviews. Most people said that behavior had changed in one way or another. Eric said that there are still many people out there who refuse to practice safe sex. Frederic, who came out late in life, had not had many sexual partners and claimed that he would have had more, had it not been for AIDS. He said that some people whom he had been sexually attracted to later turned out to have AIDS. Being a physician, he was concerned about AIDS. Ned would have liked to have the good old days back, when AIDS was not around. He claimed it is no fun being gay anymore because everything now is about AIDS. As an AIDS educator, he observed that 
many people in the gay community were in denial over AIDS and that many people had not changed their sexual behavior at all. Ned felt that AIDS had really split the gay community in two:

I know what the gay world is like. I took part in the non-infected good old days that are still going on, it's just that it's much more discreet and selective. Lots of places are prohibited to gays, if you're a known person with AIDS. ... If you have had sex with someone who tested negative and you are a person with AIDS, and they know they have had sex with you, they are wondering about the validity of their test results

I have emotional support volunteers and I have practical support volunteers, but I'm feeling no support from either because they are gay men and they are healthy and they can't stand seeing another person ill. They want to do something about it, but you can see they are questioning their own mortality, and you can see them sitting around saying "poor thing" and "what's going to happen if this happens to me?"

A number of people talked about what they saw as limited services to black gay people with AIDS, both because of public policies and the lack of black community effort.

In the HIV movement, supposedly, some of these service organizations have routinely defrauded the government. Often, the way that they have done it is in connection with services to the communities of color. Nobody has been there to police these people to see who they are actually serving. This, in the context of AIDS, is just the biggest crime of all because people are dying from it out there.

- Dave, age 41.

I also find racism and limited services to people with AIDS. At the hospital you can get $a$ in and out a lot faster if you are $a$ white man. The doctors doing medical studies now are more apt to accept whites into their studies than blacks, unless the study is designed for blacks by blacks. So, there is a lot of racism out there. 
The white gay community, when they realized that AIDS was a problem, they began to build ACT-UP and all kinds of empires of things and programs, and the black community has yet to do that. Especially the black men's community, which is the most impacted community, on a large scale has yet to do that. I think the reason for that is that we are so distracted by constantly wondering whether we're good enough.

- Karl, age 31.

Mira indicated that services to transgender people were even worse than to those of gay people:

Even the biggest AIDS organizations in town have nothing for transgender people. It is all gay oriented. They might as well exclude blacks and Filipinos and everybody else. AIDS has no gender or race. Some of us are at higher risk than others because of our lifestyles, but there is not much difference in the gay lifestyle and the transgender lifestyle except for sexual orientation. Gay people like to party all night and they are suppose to be so promiscuous and so on and so forth. The same thing with transgender people. I'm not saying that straight people are not party animals, too. I'm just saying that their lifestyle is really not that different, that they should exclude us. They are all high risk populations.

Being black and gay and HIV-posive is not easy. Most people in the sample had either experienced themselves or they had of friends who had received poor service from AIDS-related agencies. Some people expressed the feeling that one can not take an AIDS-related service model from a white gay ghetto and apply it to populations of people of color. Since many gay people of color live in their respective communities, they are harder to reach than the white gay population. 


\section{ANALYSIS}

Some of the best minds of my generation would have us believe that AIDS has brought the gay and lesbian community closer and infused it with a more democratic mandate. That is only a partial truth that further underscores the fact that the gay community still operates from a oneeyed, one-gender, one-color perception of "community" that is most likely to recognize blond before black, but seldom the two together.

Some of the best minds of my generation believe AIDS has made the gay community a more responsible social construction, but what AIDS really manages to do is clearly point out how significant are the cultural and economic differences between us; differences so extreme that black men suffer a disproportionate number of AIDS deaths in communities with very sophisticated gay health care services.

The best gay minds of my generation believe that we speak as one voice and dream one dream, but we are not monolithic. We are not even respectful of each other's differences. We are a long way from that, Dorothy. I tell you Kansas is closer.

- Hemphill, Brother, xix.

It is safe to say that AIDS has had an impact on most black gay people. Except for one person in the sample, everybody indicated that close friends or relatives had died of AIDS, and four people stated that they had tested HIV-positive. AIDS has created another stigmatized group within the gay community. As Ned explained, many places are prohibited to people with AIDS. Many people looked back on their promiscuous days, lived in constant fear of finding out that one more of their ex-partners had been diagnosed with AIDS, and worried about their own status.

Ned indicated that there were HIV-negative and HIV-positive groups in the gay community. HIV-negative people did not want to be around people with AIDS or HIV because it reminded them of their own immortality. Ned was using a 
wheelchair. He expressed that people got scared when they saw him, and that they were only able to say 'hi' to him, but could not go beyond that.

The presence of AIDS seems to have changed the sexual behavior of many people, heterosexual as well as homosexual. The sexual revolution is over and AIDS has given the moral watchdogs a new tool to use against a deteriorating morality. It is "payday" according to many. If this idea is in the minds of many heterosexuals, it is probably safe to assume that this idea is present in the minds of some homosexuals as well. Most human beings are, in one way or another, influenced by "popular opinion." The stigma attached to AIDS represents an additional disadvantage to many black gay men who already have many odds against them.

As a consequence of public policy and the treatment of African-American people in the United States for centuries, many African-American people came to believe that they were not really as good as white people. As Karl said:

Even the language, like "the black sheep of the family" and "biack magic." When you are a little black child, and everything around you, all the standards of happiness and success has white faces, that sends a message that you are less than. Then, connect that with the language, and the history of black people in this country, which is only one lifetime ago. We're not talking way back in Egypt now, we're talking about the 1600 s and a social process that went up until the late 1800 s. You cannot expect human beings to come out all perfectly functional with that type of element and the duration of that history still in our communities.

This is still the case in the conscious and unconscious minds of many AfricanAmerican people, and some of this holds true for homosexuals as well. The average gay person in the United States today will overtly and covertly get antigay messages on a daily bases. These messages can come from the church, from friends and family, from the media, and from the person's community. They can be in the form of aggressive, homophobic behavior or by simply ignoring. and not talking about, homosexuals. in some cases, this can lead to 
internalized homophobia in the gay person himself, and he can begin to question his own identity and behavior.

To a certain degree, AIDS has intensified this internal self-doubt, and made many gays ask themselves if homosexuality is wrong and if they are paying the price for what, after all, turned out to be a sin. This illustrates what Garry said about many black gay men who have tested HIV-positive feeling that they had nowhere to go. Black gay and bisexual men are in the highest risk groups for AIDS. They are harder to reach, because most of the time they are not part of the gay scene, and they are often in the closet.

According to the Centers for Disease Control, blacks are nearly three times more likely than whites to contract AIDS. A report released in May 1993 by the San Francisco Health Department revealed that young gay blacks have the highest HIV infection rate--21.2 percent--in San Francisco, while the rate among Latinos is 9.5 percent, and 8.1 percent among whites (White, A: 4). Yet, there are strong indications, as was also expressed by a number of people in the sample, that AIDS-related services for gay people of color are limited. Some people indicated that this was a direct result of racism, and gave examples of white men with AIDS getting better, faster services in the hospitals.

However, some indicated that progress was being made in the services to people of color. A number of people also claimed that the black community and black churches are now opening up and welcoming the expertise of gays and lesbians for AIDS-related education. Some people indicated that AIDS might be the issue that will push black gay people out of the closets and into their community churches, forcing black gays to be accepted both in their churches and their communities. Their leadership and expertise in AIDS education is highly needed, and some people claimed that there may be some positive side effects of AIDS. Conrad, age 51, expressed this idea: "For a long time, well still, the black community is more in denial when it comes to AIDS. Now people who were very homophobic are welcoming the experience and the help of black gays and lesbians who have been in this from the beginning and have developed expertise and so forth." 
People living with AIDS are not just sitting around waiting to die. More and more people are living long, healthy lives after they have tested HIV-positive or have AIDS. Ned reflected this reality with the plans he had:

Me and some friends will try to get to Acapulco in wheelchairs. We're leaving on September 15. It's going to take us about six weeks, travelling in our wheelchairs. ... We are all people with AIDS, so we will call ourselves "Roll AIDS" and roll ourselves down California, in to Baha in Mexico, and all the way to Acapulco where we all will have our chairs disassembled and fly back home. We have one van going with us that is kind of our maintenance man in case we get a flat or something. We don't intend getting any press coverage. We're not doing it as a benefit for anybody, and it's not a marathon or walkathon of any kind. We're just doing it. We're disabled, but we are still capable of doing this. It's something I'm looking forward to.

Mira also indicated that she had seen some progress made in medical services offered to transgender people:

I have seen some progress in the acceptance of transgender people. In medical services, seeing hormone doctors, I see a difference in the way people with HIV are treated. And in some organizations, I guess they will say, "yes, a transgender person is welcome."

AIDS has split the gay community in two. Healthy people are forming exclusive groups only for HIV-negative members. Some people are still living in denial of the fact that AIDS exists, while others pointed out that the whole gay movement, which used to be filled with fun and happiness, has now turned out to be an AIDS movement instead. Black, gay, HIV-positive men often find themselves without a support-network when they get sick, and many internalize the difficult struggle between racism, homophobia, and the stigma of having AIDS. 


\section{RELIGION AND SPIRITUALITY}

In the old testament, in Sodom and Gomorrah, a lot religious people claim that God destroyed Gomorrah because of homosexuality there. The reason you know there is homosexuality in that particular passage in the Bible is because when God sent some angels to Gomorrah, they found ten righteous people. They were obviously very beautiful angels and some of the guys hit on them, made passes at them. You have some people in some religious thinkings saying that that's another example of how God views homosexuality, when the truth of the matter is, that God destroyed Gomorrah because of its overall ways. They could not find one righteous person in that whole city, so he destroyed it. So, it had nothing to do specifically with homosexuals.

- Eric, age 36.

People in the sample were asked the following question regarding religion and spirituality: "What role, if any, does religion or spirituality play in your life?" Approximately half of the sample expressed that religion played an important part in their lives, while the other half said it played an insignificant role or no role at all. Some people went to gay churches regularly. The majority of people, who considered themselves religious, were either Catholic or Baptist. Some were concerned about homophobia and what they expressed as contradictions and hypocrisies in church. A number of people were in the process of finding a gay church as an alternative to the church that they had been going to.

Eric pointed to the fact that, if you go to a traditional Southern Baptist church with a black congregation, you will have "queens running all over the church," especially in the choir. For some reason, homosexuality seems to be accepted on that level. At the same time, ministers preach that homosexuality is a sin. Karl had what he described as "anti-religious views." He claimed that the black community was drawn towards the church because black people have had so 
many things taken from them, and were so deprived. that they clung to church as a place of hope, to get some relief.

About half the sample responded affirmatively to the question of religion, but not without reservations toward what they considered less desirable aspects of the church. Dave came from a family of preachers. He had a strong spiritual feeling, but he claimed that very few churches gave him a combination of the things that he wanted in a church, like "the African-American style gospel and spiritual type of worship; the positive non-sexist, non-homophobic aspects of some of the new churches; and just the level of upper-middle class church tradition that I am accustomed to." Eric self-identified as a Christian. He stated that "once you accept Jesus Christ as the savior" you cannot live any way you want, that there is a responsibility that goes along with being a Christian. This created a dilemma for him because he became "convicted by his own convictions." Like he said: "I am now prisoner of my own conviction. That probably has something to do with the fact that I am not sexually active." Conrad went to a gay church. It was not Baptist, but he said it felt like Baptist. The minister there was black, and the script came from the Bible. He had always been religious, but left the church as a young man because he could not deal with the hypocrisy and homophobia.

The other half of the sample responded that religion had not played an important role in their lives, for different reasons. Frederic was not religious but dealt with religion when he went to gay AA meetings. He explained that many people were there because of what religion had done to them, in terms of being told that they would never get into heaven because they were queer. Karl was strongly against organized religion: "I think organized religion is a bunch of bullshit. I' $m$ not confused about that at all. Organized religion teaches severely insecure people to submit to the evil of some jerk. That's what I think!" Bern went to a gay church for a period of time, but he did not consider himself religious: "I have more of a personal relationship with God, than anything else." 
Some people expressed feelings about what they considered hypocrisy, or contradictions, in the church:

I'm amazed, even at the African-American gay church here in the city. It has two female pastors and they preach all this stuff about a masculine god. To me it's a classic example of how deep-rooted oppression is. I can better tolerate listening to these old African-American preachers talk down on gays, than I can stand listening to women preachers talk about a masculine God --get a grip! (laughter). You're suppose to be liberating us, not turning us 2000 years back in time on these issues.

- Dave, age 41.

I studied hard to become a priest. I wanted to become a priest, a gay priest. I think it's healthy. I think gay men and lesbian women can make wonderful priests. And I think it should be that way. But there are so many closets in the Catholic church. The priests are so fucked up. They are alcoholics because they are living a lie. They are stuffing their sexuality; this celibate crap is for the birds. It's a bunch of bogus crap. I'm gay, that's why I could not become a priest. But I could have become a priest if I would pretend that I'm not sexually aroused by men, but I could still be gay. This is what the Catholic church says. You can be gay but you cannot be sexually active. Yet, the Catholic church teaches you to be honest. It's so hypocritical that i just could not become involved in that. If I chose to be who I am over religion, then I have very strong sense of who I am.

I went to a monastery in Europe. The one I stayed in in Germany was very sexually active (laughter). It was great. It was very open within that community. There were men there who wished not to participate in it, and they didn't. The first night I was there in the monastery there was a little tap on my door (laughter). Europeans are so much more ahead of Americans anyway when it comes to sexuality. I decided not to become a priest because I chose my sexuality over my religion. That's why I feel good about God today.

- Lang, age 52.

The things that stand out in the black community, which tend to have a great impact on how people deal with the comfort level of their sexuality, are under the influence of what I call the Euro-Christian church. The model of Christianity in this country, which includes 99 percent of the churches, is European, white interpretation of the church, which is anti-black, and contradictory. If you read the description of Jesus Christ in the Bible, it does 
not describe the blond, blue eyed picture. There's a contradiction right in the pages. Every leader who is legitimized in this country who is black, is a minister. Reverend Jessie Jackson and Reverend Martin Luther King and so the list goes on. So the dominant culture allows us to have leaders who are caught up in what I consider Euro-Christian bull, which is very controlling. If you are not into that shit, you don't get to be a leader who is legitimized by the dominant culture, or get press.

- Karl, age 31.

This lack of tolerance in the traditional church made some look for other alternatives. Eric's uncle was a minister in the church that he went to, so he met a lot of his relatives there and considered it a good opportunity to meet his family on a regular basis. However, as he explained; "They are death on homosexuality. Specifically homosexuals. I doubt I will continue to go there," (laughter). Eric considered finding a gay church to attend.

Most people in the sample considered it a contradiction for a gay person to attend a regular church, because of the homophobia preached there. This was expressed by people who did not consider themselves religious as well as the religious segment of the sample. Lang pointed out that one of the contradictions in the church with respect to homosexuality was the fact that the preachers preached that it was a sin, but at the same time many priests engaged in homosexual activities themselves. Some people in the sample were attending gay churches. They felt that that was a place where they could express and receive spirituality, and at the same time, be who they were. Some of the religious people in the sample stated that they had problems finding a church capable of giving them what they wanted in a church. This was because the gay churches were often very different from the churches that they had grown up with. The churches they had grown up in, most often Baptist, were homophobic. 


\section{ANALYSIS}

To understand the power of the Black Church it must first be understood that there is no disjunction between the Black Church and the Black community. The church is the spiritual face of the Black community, and whether one is a "church member" or not is beside the point in any assessment of the importance and meaning of the Black Church .... The Black Church, then, is in some sense a "universal church," claiming and representing all blacks out of a long tradition that looks back to the time when there was only the Black Church to bear witness to "who" or "what" a man was as he stood at the bar of his community. The Church still accepts a broad-gauge responsibility for the Black community inside and outside its formal communion. No one can die "outside the Black Church" if he is Black. No matter how notorious one's life on earth, the Church claims its own at death - and with appropriate ceremony.

- Lincoln in Paris, 8.

The topic of church and religion was brought up in a number of contexts during the interviews. The church functions at the center of the lives of many black communities, both historically and today. Therefore, most people living in the black community have been influenced by the church in one way or another. Historically, the church has had many important roles. The civil rights movement was anchored in the black church. Two aspects of the black church will be discussed in this section: First, the element of homophobia according to the sample, then some of the social influences of the church in the black community.

Those people in the sample who considered themselves religious usually had gone to church frequently during their childhood. Most of them said they loved gospel music, and that they would have continued going to their traditional church had it not been for the homophobia there. A number of the people in the sample claimed that the church was the strongest source of homophobia in the black community. If a black gay man wishes to go to a traditional black church, he will hear homophobic comments from the preacher and other people in church. If one wishes to attend church with an open gay agenda, one will have 
to withstand a lot of hostility. As a result, most people in the sample stopped going to the traditional churches after defining their own homosexuality.

As a number of the people in the sample pointed out, the church is hypocritical when it comes to gay issues. As Lang pointed out, the Catholic church says that one can be homosexual, but that you cannot practice homosexuality. Yet, many of the priests are gay. This is another example of the fact that, in institutions where people of the same gender come together, some same gender sex is likely to take place.

Religion is often used to control people in their behavior. For many people, the church represents what they see as their connection to higher powers, powers which control every aspect of life and death. If you can make people believe in this, you can manipulate people into doing anything and everything. Sexual instincts are strong in most people. In order for the church to control people, they need to put taboos on sexuality.

Christianity originally provided the major legitimation for the system of slavery in the United States, but eventually it also stimulated the moral impulses for its abolition (Lincoln and Mamiya, 281). The black church has played important social roles in the black community. The most potent catalyst for the black consciousness movement was the civil rights movement led by Dr. Martin Luther King, Jr. From the beginning, the civil rights movement operated to a large degree from the black church, organized by activist black ministers, and supported financially by black church members. As Aldon Morris has written, it was the black church which provided an "ideological framework through which passive attitudes were transformed into a collective consciousness supportive of collective action" (Lincoln and Mamiya, 165).

In summary, some of the people in the sample considered themselves religious, and most people had had connections to the church at one point in their lives. Most people recognized the homophobia in the black church. Yet, the church still played a major part in the lives of a number of people, and a very important social function in the black community. 


\section{iX CONCLUSION}

Black gay men often find themselves torn between the gay and the black communities, without being fully accepted in either. The gay community is as racist as the rest of the society, and it is hard for a black man to gain respect and become a community leader. Often the only black men who gain status in the gay community are so called white people with black faces, often with a white lover by their side. Black gay men are often interesting to white men only because of the historical mystique associated with black sexuality. Still, it is important to note that not every inter-racial relationship in the gay community is based on this sexual exploitation. Some of the men interviewed seemed to have healthy relationships with white men or men of other ethnic backgrounds.

Black gay men are accepted in the black community only if they stay in the closet. The black community is willing to accept deviance if it is not talked about. However, it is not willing to accept an openly gay agenda. The church plays a very significant role in the black community, and can be seen as the force behind much of the homophobia expressed. There are some indications that this might slowly be changing as the black community is in great need of expertise from the gay community in fighting AIDS. Some of the AIDS educators in the sample were beginning to gain entrance into the black churches for the purpose of AIDS education.

Defining a gay identity can be a long and hard process or it can just be a natural extension of who the person is. Some black gay men go through a process of exploring their sexuality with women before they identify as gay. Some research indicates that black men are more likely to be bisexual. This may have more to do with the strong value placed on family in the black community, which leads some men to have families first, later exploring their homosexuality on the side. 
Blacks have a strong concept of family. Many households are run by a very strong mother-figure, and she usually gains high respect from her children. In return, she will not write off her children for deviant behavior, though she might not openly approve of their homosexuality and will often put up a fight for what she thinks is the best for her children. The father is sometimes absent in this family picture, but he will often be close by to help and support his children.

Transgender people do not consider themselves part of the gay community, and feel mistreated by gay people. Gay people often look upon transgender people as being the extreme and negative aspect of the heterosexual stereotype of gay men. Therefore, many gay people will react negatively towards transgender people out of the fear of being associated with feminine behavior. Transgender people have very limited opportunities, and often end up on the streets as prostitutes as a result of a total lack of other support networks.

AIDS has affected the black gay and transgender communities severely. Black men are among the highest risk-groups for contracting AIDS, and have the most limited opportunities to receive AIDS related services. The public funding for AIDS related services to the gay community has been patterned for white gay men. Black gay men are harder to reach because they often stay in the closet in the black community. As a consequence, they are left out of the projects designed both for the gay white population in the gay community and those designed for the black heterosexual population in the black community. More resources are needed for AIDS related services to populations of gay people of color, because they are harder to reach and often have a stronger connection to their ethnic communities.

This thesis was designed to collect information on a population to whom little research has been devoted in the past. I hope this thesis will serve the purpose of pointing to areas for future research. Personally, I see this most clearly in the area of transgender issues. Very little information on transgender people is available, except for a few papers classifying different categories of transgender people. This population is systematically left out of every research because of the difficulty in fitting transgender people in with other categories of people. 
Few gay resource centers have services for transgender people. Transgender people, on the other hand, do not consider themselves to be gay. More resources are badly needed to educate public service organization on how to better serve the transgender population.

The issues addressed in this thesis were at times very heavy and personal, both for me as an interviewer and for the people I interviewed since they disclosed very personal, and sometimes very painful, memories and events. At times a few tears were shed. Still, what I will remember the most about the people and the interviews will be the great humor used even in the darkest of moments. If I were to do a similar project over again, an additional research question would be: "Where do black gay men get their wonderful humor from?" 


\section{BIBLIOGRAPHY}

Anbian, Robert. "An Interview with Marlon Riggs: Tongues Untied Lets Loose Angry, Loving Words." Release Print March 1990: 5.

Baldwin, James. Giovanni's Room. New York: Dell Publishing, 1956.

Beam, Joseph. In The Life: A Black Gay Anthology. Boston: Alyson Publications, Inc., 1986.

Bennett, Lerone Jr. Before The Mayflower: A History of Black America. Harrisonburg: R.R. Donnelley \& Sons Company, 1988.

Beran, Nancy J., et al. "Attitudes Toward Minorities: A Comparison of Homosexuals and the General Population." Journal of Homosexuality 23 (1992): 65-83.

Blackwood, Evelyn. Anthropology and Homosexual Behavior. New York: The Haworth Press, Inc., 1986.

Bullough, Vern L., and Bonnie Bullough. Cross Dressing, Sex, and Gender. Philadelphia: University of Pennsylvania Press, 1993.

Clarke, Cheryl. "The Failure to Transform: Homophobia in the Black Community." Home Girls: A Black Feminist Anthology. Ed. Barbara Smith. New York: Kitchen Table Press, 1983

Cone, James H. Martin \& Malcolm \& America. New York: Orbis Books, 1991.

Docter, Richard F. Transvestites and Transsexuals: Toward a Theory of Cross-Gender Behavior. New York: Plenum Press, 1988.

Feinblom, Deborah Heller. Transvestites and Transsexuals. Seymour Lawrence: Delacorte Press, 1976.

Giles, Jeff. "The Crying Game." Rolling Stone 1 April 1993: 36.

Hemphill, Essex., ed. Ceremonies: Prose and Poetry. New York: Penguin Books USA Inc., 1992.

Hemphill, Essex, and Joseph Beam, comps. and eds. Brother to Brother. Boston: Alyson Publications, 1991. 
Herd, Gilbert. The Sambia: Ritual and Gender in New Guinea. Chicago: Holt, Rinehart and Winston, Inc., 1987.

Icar, Larry. "Black Gay Men and Conflicting Social Identities: Sexua! Orientation Versus Racial Identity." Journal of Social Work and Human Sexuality 4 (1986): 83-93.

Langness, Lewis L. The Life History in Anthropological Science. New York: Holt, Rinehart and Winston, inc., 1965.

Lincoln, C. Eric, and Lawrence H. Mamiya. The Black Church in the African American Experience. Durham: Duke University Press, 1990.

Little, Malcolm. Autobiography of Malcolm X. New York: Grove Press, 1965.

Marcus, Erik. Making History: The Struggle For Gay And Lesbian Equal Riahts. New York: Harper Collins Publishers, 1992.

Nanda, Serena. Neither Man nor Woman: The Hijras of India. Belmont: Wasworth Publishing Company, 1990.

Ortner, Sherry B., and Harriet Whitehead. Sexual Meanings. New York: Cambridge University Press, 1991.

Paris, Peter J. The Social Teaching of the Black Churches. Philadelphia: Fortress Press, 1985.

Riggs, Marlon T., dir. Tonques Untied. San Francisco: California Newsreel, 1991.

Ross, Michael W. Homosexuality And Social Sex Roles. New York: The Haworth Press, 1983.

Saint, Assotto, ed. Here to Dear: 10 Gay Black Poets. New York: Galiens Press, 1992.

Saint, Assoto, ed. The Road Before Us: 100 Gay Black Poets. New York: Galiens Press, 1991.

Sheridan, Earl. "The Diminishing Soul of Black America." Social Theory and Practice 14 (1988): $131-40$.

Sitkof, Harvard. The Struggle For Black Equality. New York: Hill and Wang, 1981.

Staples, Robert. The Black Family. Belmont: Wasworth Publishing Company, Inc., 1971. 
Staples, Robert. Black Masculinity. San Francisco: The Black Scholar Press, 1982.

Staples, Robert. The World of Black Singles. Westport: Greenwood Press, 1981.

Stewart, Charles. " Double Jeopardy: Black, gay (and invisible)." The New Republic. 2 December 1991: 13-15.

Tremble, Bob, Margaret Schneider, and Carol Appathurai. "Growing Up Gay or Lesbian in a Multicultural Context." Journal of Homosexuality 17 (1989): 253-67.

White, Evelyn C. "Bias from Within Against Black Gays." San Francisco Chronicle [San Francisco] 26 June, 1993, sec. A: 4.

Williams, Lena. "Separate \& Unequal." San Jose Mercury News [San Jose] 3 July, 1993, sec. C: 1.

Williams, Walter L. The Spirit And The Flesh. Boston: Beacon Press, 1992.

Wilson, Arthur T., et al. Here to Dare. New York: Galiens Press, 1992.

Yingling, Thomas. "Sexual Preference/Cultural Reference: The Predicament of Gay Culture Studies." American Literary History 3 (1991): 184-97. 